\title{
A review of Fennoscandian arthropods living on and in snow
}

\author{
SIGMUND HÅGVAR \\ Department of Ecology and Natural Resource Management, Norwegian University of Life Sciences, P.O. Box 5003, N-1432 Ås, \\ Norway; e-mail: sigmund.hagvar@umb.no
}

Key words. Arthropods, winter activity, snow, adaptations, migration, orientation, Fennoscandia, review, Collembola, Hypogastura, Diptera, Chionea, Trichocera, Mecoptera, Boreus, Araneae, Bolephthyphantes, subnivean, intranivean, supranivean

\begin{abstract}
A permanent snow cover for several months is typical for large parts of Norway, Sweden and Finland. Snow layers thicker than about $20 \mathrm{~cm}$ insulate the soil surface and stabilize the ground temperature close to $0^{\circ} \mathrm{C}$. Many ground-living invertebrates are active at this temperature in the subnivean air space. From this "base camp", some invertebrates migrate upwards to use the snow as a substrate. The intranivean fauna consists of springtails (Collembola) and mites (Acari) that are small enough to move within the narrow pores between snow crystals. The supranivean fauna consists of various invertebrates that are active on the snow surface. Some of them are Collembola that have migrated through the snow layers. However, most of them are larger insects and spiders which migrate between the subnivean and supranivean habitats following air channels which are naturally created along tree stems, bushes etc. penetrating the snow. Likewise, certain Chironomidae and Plecoptera, hatching from winter-open rivers and brooks, are active on the snow surface. The supranivean arthropod fauna has the following characteristics: 1. It is a weather dependent assemblage of species, coming and going with changes in air temperature, cloud cover, and wind. Below ca. $-6^{\circ} \mathrm{C}$ animals are absent, but at temperatures around or above zero, many groups can be simultaneously active on snow. 2. The snow surface fauna shows phenological changes throughout the winter, as certain species and groups are mainly active during certain months. 3. Some invertebrates are highly specialized and take advantage of the snow surface as an arena in their life cycle. Examples are Hypogastrura socialis (Collembola), and the two wingless insects Chionea sp. (Diptera: Limoniidae) and Boreus sp. (Mecoptera). They use the smooth snow surface for efficient migration. Chionea sp. and Boreus sp. lay their eggs during the snow-covered period, while H. socialis migrates to create new colonies. The cold tolerant spider Bolephthyphantes index is unique in constructing webs in small depressions on the snow, to catch migrating Collembola. Various adaptations for using the snow as a substrate are discussed. Besides physiological and morphological adaptations, snow surface arthropods show special behavioural adaptations. Most conspicuous is the ability of several Collembola species to navigate during migration, using the position of the sun for orientation. Furthermore, in Collembola and Mecoptera, jumping as an original mechanism to escape predators has independently evolved into a migrating mechanism. An evolutionary potential exists for more invertebrate groups to take advantage of snow as a substrate in their life cycle. For instance, several more cold tolerant spiders might evolve the ability to catch migrating Collembola on snow.
\end{abstract}

\section{INTRODUCTION}

In parts of Norway, Sweden and Finland, the snowcovered period may last for up to six months. When the thickness of the snow cover exceeds about $20 \mathrm{~cm}$, defined as the "hiemal threshold", the soil surface and the subnivean air space are insulated, and the temperature here stays close to $0^{\circ} \mathrm{C}$ (Coulianos \& Johnels, 1962; Geiger, 1965; Pruitt, 1970). While most Fennoscandian terrestrial arthropods pass the winter in an inactive state, certain species are able to be active on or within the snow as a part of their life cycle. Most of them colonize the snow from the ground below, and retreat to this habitat, if the temperature becomes too low. However, imagines of certain freshwater insects (Plecoptera and Diptera, Chironomidae) are also active on the snow surface after hatching from open rivers and brooks.

Ecologically, the snow layer creates three different microhabitats: below snow (subnivean), within snow (intranivean), and the snow surface (supranivean), each with its characteristic arthropod fauna (general summary by Aitchison, 2001).

The subnivean fauna, which has been studied by pitfall trapping below the snow, includes a number of groups, e.g. oligochaetes, molluscs, centipedes, pseudoscorpions, spiders, mites, springtails, beetles, flies, wasps and other insects (e.g. Näsmark, 1964 in Sweden; Koponen, 1976 and Viramo, 1983b in Finland; Aitchison, 2001 in Canada; Vanin \& Turchetto, 2007 in Italian mountains). Most of these invertebrates remain in the subnivean space, and little is known about the function of their winter activity. This paper discusses only those species that migrate upwards into the snow layers or up to the snow surface, i.e. those that actively use the snow as a substrate.

The intranivean fauna consists mainly of springtails and mites that migrate up into the snow (BrummerKorvenkontio \& Brummer-Korvenkontio, 1980; Leinaas, 1981a). These microarthropods are small enough to move within the narrow pores between snow crystals, and some species also reach the snow surface. Their vertical migrations within snow are strongly influenced by snow temperature, and during cold periods, they are forced down to the lowest snow layers or even back to the subnivean air space (Leinaas, 1981a). Larger arthropods (spiders and insects) that migrate between the subnivean and the supranivean habitat cannot pass directly through the snow 

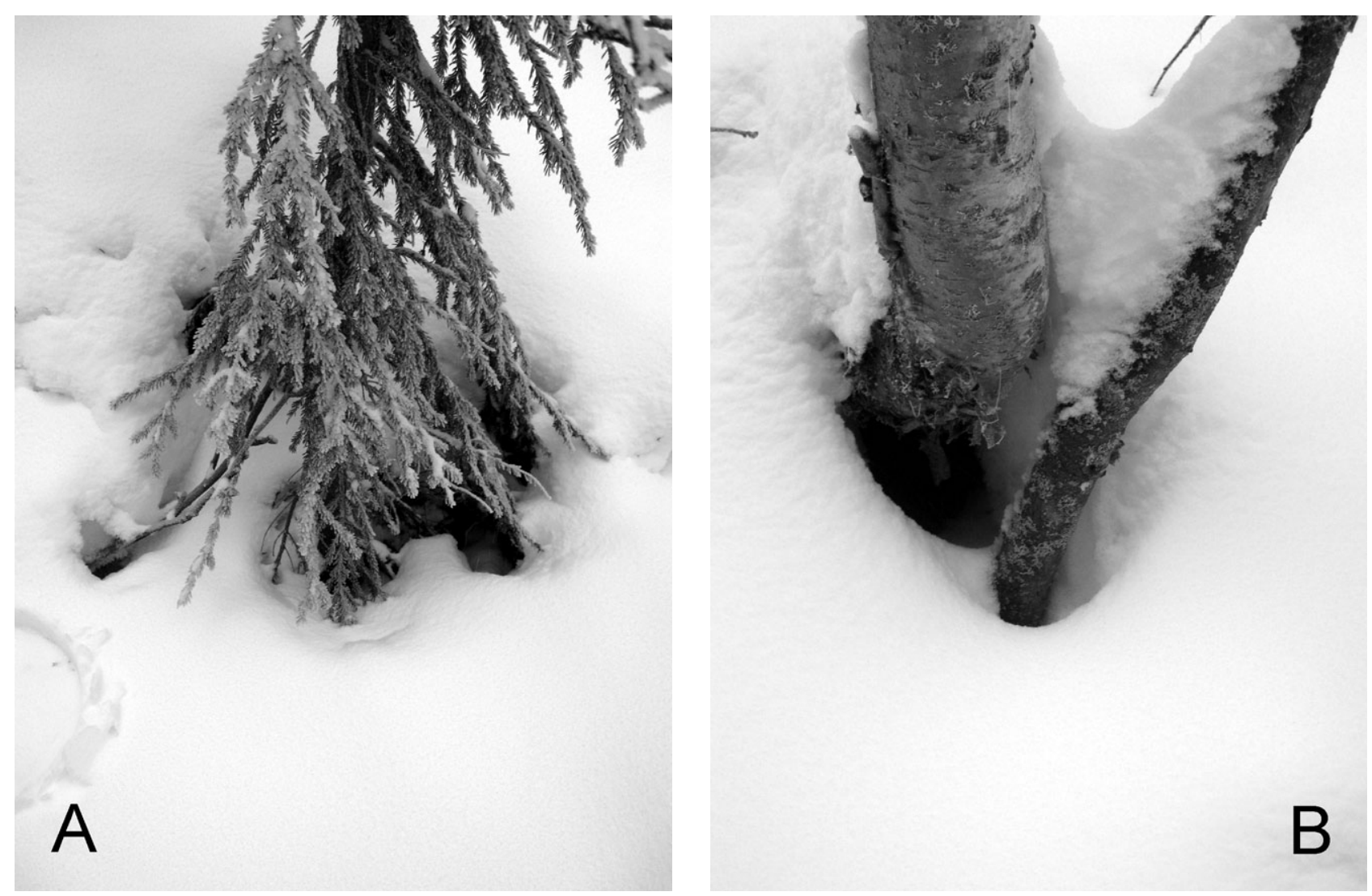

Fig. 1A-B: Air spaces that are created along protruding vegetation allow arthropods to migrate between the subnivean and supranivean environments. A - channels through the snow along lower spruce branches and B - along a birch stem. Photo: S. Hågvar.

layers, but have to follow air spaces along vegetation, such as tree trunks and bush branches, penetrating the snow (Fig. 1). Although in this way they travel vertically through the snow cover, they are not included here in the intranivean fauna.

The supranivean fauna contains the most specialized winter active arthropods. Most remarkable are the two wingless insect genera Chionea Dalman (Diptera: Limoniidae) (Fig. 2) and Boreus Latreille (Mecoptera). Several springtail (Collembola) species are also regularly active on the snow surface (Tahvonen, 1942; BrummerKorvenkontio \& Brummer-Korvenkontio, 1980; Leinaas, 1981a, 1983c; Hågvar, 1995, 2000). Other typical snow surface insects in Fennoscandia are the winter gnats (Trichoceridae) (Tahvonen, 1942; Dahl, 1969; Hågvar \& Krzeminska, 2007), and a number of fly species (Diptera Brachycera) (Hågvar \& Greve, 2003). From open brooks and rivers, certain species of Plecoptera (Ulfstrand, 1968) and Chironomidae (Hågvar \& Østbye, 1973; Jonsson \& Sandlund, 1975) hatch during the winter and are active on snow. Among a large number of spider species that can be encountered on snow (e.g. Huhta \& Viramo, 1979; Hågvar \& Aakra, 2006), only one Fennoscandian species, Bolephthyphantes index (Thorell) uses the snow surface regularly for web building (Hågvar, 1973). Many other invertebrate groups can be found occasionally on snow, for instance hibernating Psyllidae and Heteroptera blown down from trees (Hågvar, 2007), or beetles having been activated by warm weather. Tahvonen (1942) listed many different insects found on snow in Central Finland, and Koponen (1983) and Viramo (1983a, b) described the arthropod fauna on snow in Northern Finland. Svensson (1966) described the biology of typical snow-surface insects in Sweden.

A special supranivean beetle fauna can be found in the alpine areas of Fennoscandia: Certain Coleoptera are active during summer on snow or ice fields or glacier tongues, hunting invertebrates brought by warm winds from the lowlands and dropped over the cold snow and ice (Østbye, 1963). However, since this is a summer phenomenon, it will not be discussed further here.

Winter activity requires special physiological adaptations. For instance, several winter-active arthropods are able to move in a supercooled state (Sømme \& Østbye, 1969; Hågvar, 1973). Husby \& Zachariassen (1980) showed that Boreus westwoodi Hagen and Bolephthyphantes index were able to be active at subzero temperatures on snow due to unidentified antifreeze agents in their body fluid. While the body fluid had a melting point of about $-1^{\circ} \mathrm{C}$, a drop of body fluid containing a tiny ice crystal could be cooled down to -6 to $-7^{\circ} \mathrm{C}$ before freezing. The presence of antifreeze agents in certain Collembola was demonstrated by Zettel (1984b). Vanin et al. (2008) showed that the sugar trehalose was the antifreeze agent in the haemolymph of snow-active Boreus hyemalis (L.), Chionea sp. and cantharid larvae (Coleoptera: Cantharidae). Hågvar (1976b) observed that Chionea araneoides individuals were still alive after being enclosed in 


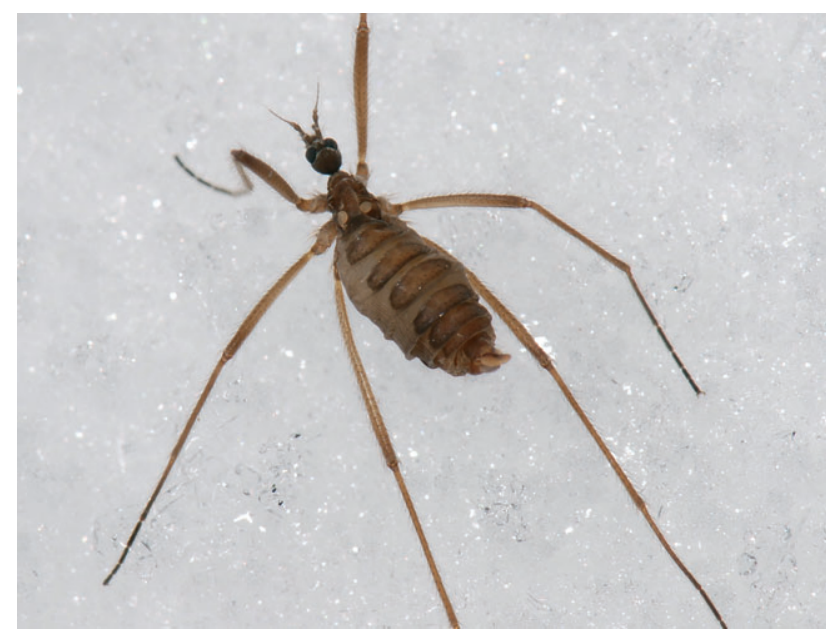

Fig. 2. A female of Chionea araneoides walking on snow. Photo: N. Sloth.

ice due to supercooled rain. Obviously, the body fluid had not frozen.

The mechanism of supercooling is also extensively found in hibernating, inactive terrestrial arthropods, since they are usually freeze intolerant. While inactive arthropods can use antifreeze agents that make the haemolymph viscous, winter active species have to use antifreeze agents which allow the haemolymph to circulate easily (Husby \& Zachariassen, 1980; Vanin et al., 2008). A general review of the physiology of cold hardiness in terrestrial arthropods has been compiled by Sømme (1999).

\section{DIFFERENT TAXA OF "SNOW ARTHROPODS"}

"Snow arthropods" can be grouped ecologically in different ways, as discussed later. The following presentation follows a taxonomical line starting with Collembola, followed by Mecoptera, various Diptera, Plecoptera and Araneae.

\section{COLLEMBOLA}

\section{Phenology}

In Fennoscandia, several species of Collembola (springtails) may be active on snow at temperatures close to $0^{\circ} \mathrm{C}$, or slightly above. They can be seen throughout the winter, but most typically in late winter when the overall temperature is higher. The most common species is Hypogastrura socialis (Uzel) (Hypogastruridae).

\section{Hypogastrura socialis}

In order to understand the winter activity of this species, the whole life cycle throughout the year has to be considered (Leinaas, 1983c). During the summer, this species lives in highly aggregated colonies. They are typically situated in well-drained heaps of needle litter below certain spruce trees (Leinaas, 1981a). Sooner or later the colony has to move, at least when the litter-producing tree dies. In ecological terms, the species lives in a patchy and temporary habitat. Slow migration of entire summer colonies of $H$. socialis on bare ground has been observed a few times in Norway (Hågvar \& Fjellberg, 2002; Skulberg \& Skulberg, 2003) and in Germany (Zernecke,

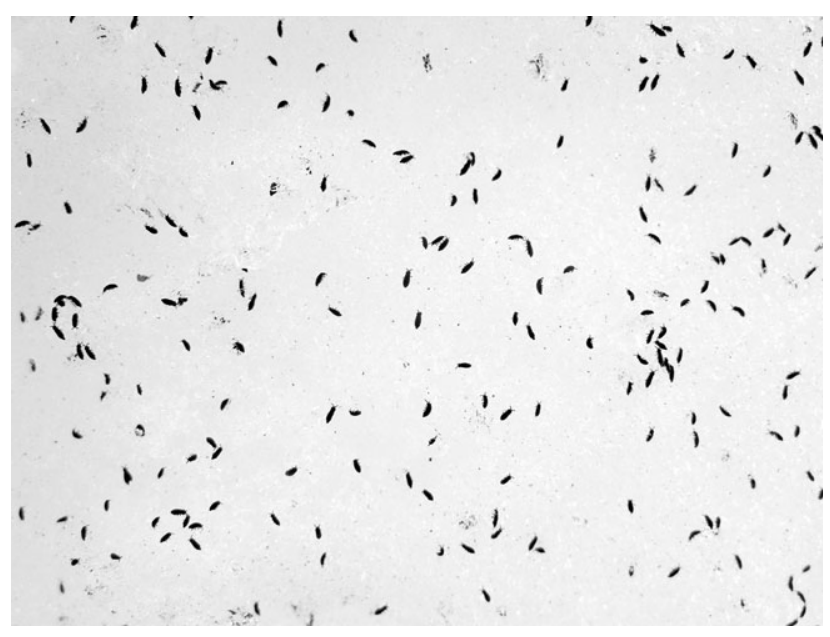

Fig. 3. A mass occurrence of the springtail Hypogastrura socialis in a depression in the snow. Each animal is about 1.2 $\mathrm{mm}$ long. During sunny weather at temperatures above zero, the animals show an intense migration behaviour. Photo: H. J. Skar.

1999). Visually, the colony looks like a dash of violet paint that has been poured out on the forest floor. This is probably a feeding migration for the colony, a summer behaviour that is also known for colonies of Ceratophysella sigillata (Uzel) in the same family, observed in Switzerland (Zettel et al., 2002). In H. socialis, wintertime is typically used for efficient migration on the snow (Fig. 3). During late winter, the animals start to aggregate again. New colonies with new genetic combinations are established on early snow-free patches below selected trees. Through chemical communication, moulting and egg-laying occur simultaneously during spring, and the old animals die (Leinaas, 1983a, b).

\section{Other species of Collembola}

Other characteristic species on snow in mild weather are the closely related Hypogastrura lapponica (Axelson) (Leinaas, 1981c) and the three Isotomidae species Vertagopus westerlundi (Reuter), Isotoma hiemalis Schött, and Isotoma violacea Tullberg (Hågvar, 2000). Likewise, their winter migration on snow may be explained by their occupation of patchy and temporary habitats during the snow-free period. Colonies of $H$. lapponica are situated under the bark of old birches, $V$. westerlundi lives among lichens at the base of certain spruce trunks, and $I$. violacea is restricted to needle heaps below spruce trees (Leinaas 1980, 1981a, c; Leinaas \& Fjellberg, 1985). According to Leinaas (1981a and pers. comm.), I. hiemalis is distributed throughout the year over the whole forest floor in spruce forests, but prefers moist patches in dry pine forests. In Switzerland, where the species is active on snow in subalpine spruce forest, it occurs only in moist accumulations of needle litter during the summer (Zettel, 1984a, 1985). Hence, at least in parts of its range, the ability of winter migration may be important. Recently, I. hiemalis has changed name to Desoria hiemalis (Schött), and I. violacea to Desoria tolya Fjellberg (Fjellberg, 2007), but the old names are kept here for practical reasons. 


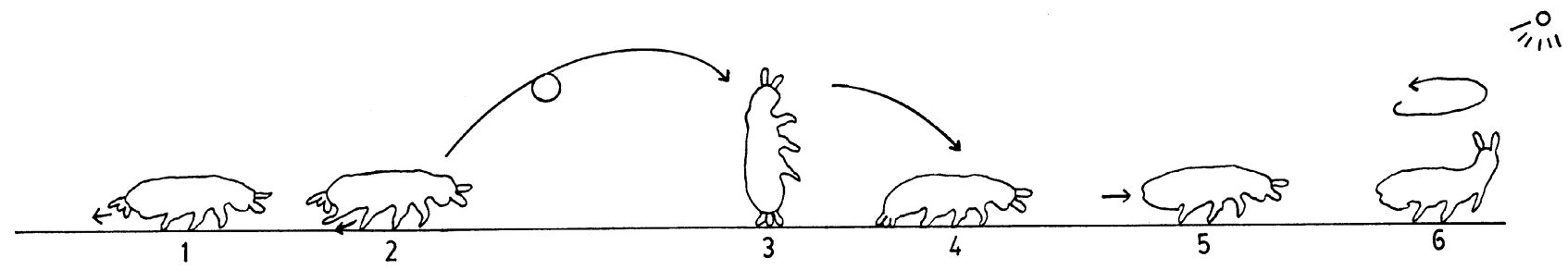

Fig. 4. Six phases during one jump in the springtail Hypogastrura socialis. 1. The animal contracts its body and extends the anal sacks. 2. The furca is released and the animal jumps. 3. Anal sacks "glue" the animal to the snow at landing and stop rotation. 4 . The animal bends forward and grips the snow. 5. The anal sacks are withdrawn. 6 . The animal rotates horizontally on the spot and positions itself for another jump at a certain angle relative to the sun. From Hågvar (2000).

\section{Life of Collembola within and on snow}

Due to their small size, Collembola are able to migrate vertically within the snow, as long as they are not stopped by compact snow layers or low temperatures. They are thus active both in the subnivean, intranivean and supranivean environment. Brummer-Korvenkontio \& Brummer-Korvenkontio (1980) and Leinaas (1981a, 1983c) showed that most surface-living Collembola species in coniferous forests migrate up into the lower snow layers during winter. Leinaas (1981a, 1983c) assumed that the animals in this way avoid unpredictable and harmful water-logging or freezing of the uppermost soil layer. He showed that especially Hypogastrura socialis tried to reach the snow surface and tolerated a snow temperature of about $-4^{\circ} \mathrm{C}$. While the Collembola were forced down to lower and warmer snow layers during cold spells, the whole population of $H$. socialis rapidly entered the snow surface when snow and air temperatures were around $0^{\circ} \mathrm{C}$. Leinaas $(1981 \mathrm{a}, 1983 \mathrm{c})$ regarded the horizontal activity on the snow surface as being an evolutionary extension of the vertical migration within the snow layers, and assumed that surface activity had developed further into a dispersing behaviour in $H$. socialis.

\section{Migration and jumping behaviour of $H$. socialis}

Effective migration on snow requires non-random movements, and preferably an ability to keep a steady course over longer distances. Hågvar (1995) showed that individuals of $H$. socialis were able to navigate by using the position of the sun. This could be demonstrated by manipulating the sun's position with a mirror. In a coniferous forest, each animal kept a fixed direction on the snow surface. By continuous jumping up to $80 \mathrm{~cm}$ could be covered per minute in sunny weather with air temperatures well above $0^{\circ} \mathrm{C}$. It was estimated that an animal could cover $200-300 \mathrm{~m}$ in a day, enabling them to cross habitats that would otherwise represent physical barriers in the landscape (e.g. rivers, wetlands and lakes). If the temperature dropped below zero in the evening, the animals simply retracted down into the snow layers. In two cases, animals reappearing to the surface next morning seemed to remember the direction from the preceding evening, indicating an inner clock. It is not known whether the animals may adjust for the sun's movement during the day, but even if their route makes a daily arch, a main direction is being kept. Since they were able to proceed navigating in the shade and even after sunset, i.e. without a visible sun but with patches of blue sky, Hågvar (1995) suggested that they might be able to see polarized light.

During mass migrations of $\mathrm{H}$. socialis in a forest landscape of many $\mathrm{km}^{2}$, densities around 4000 animals per $\mathrm{m}^{2}$ snow surface have been repeatedly observed (Leinaas, 1981a; Hågvar, 2000). Within a given $\mathrm{m}^{2}$, individual animals may migrate in different directions simultaneously, both relative to the sun and relative to the compass. They all use the sun's position as a guide, but have for some unknown reason decided on different directions. Mass migration in all directions results in efficient spreading of the species and genetic mixing in the new colonies.

Fig. 4 illustrates six phases during one jump in $H$. socialis (Hågvar, 2000). Leinaas (1981b) showed that the winter form of $H$. socialis had larger spines on the furca than the summer form, allowing the animals to get a good grip on the somewhat slippery snow surface during winter dispersal.

During completely overcast weather the animals are more or less inactive on snow, and if they jump, the direction may be more or less random. Some cases of successful directional jumping in overcast weather were probably due to orientation based on dark and light objects in the surroundings (Hågvar, 2000).

An animal keeping a constant direction on snow (Fig. 5) faces a problem when meeting obstacles like tree stems. Hågvar (1995) showed experimentally that individuals of $H$. socialis turned to one side when being close to a dark object, went around it and then resumed their original direction. However, sometimes animals are

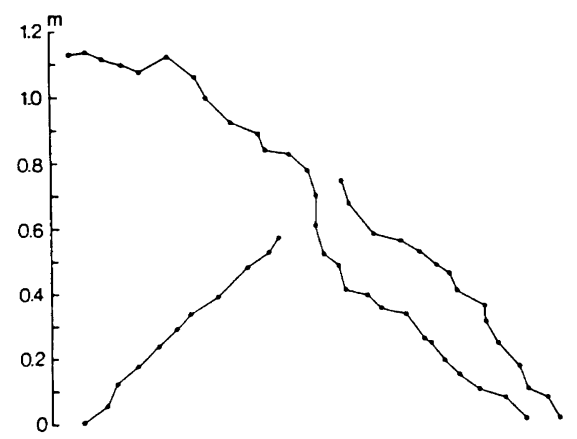

Fig. 5. Directional movement on snow of three Hypogastrura socialis individuals. Different individuals often choose different direction. Dots indicate starting points for each jump. From Hågvar (1995). 


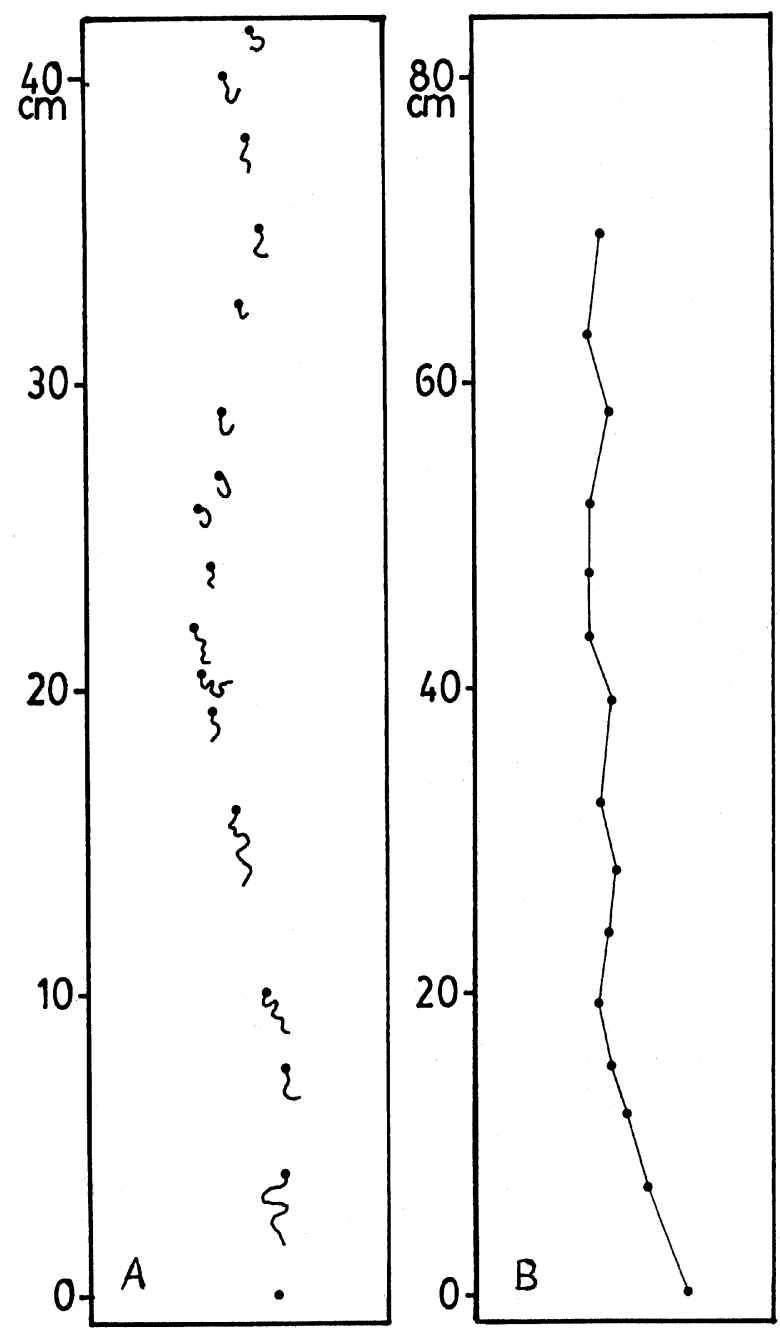

Fig. 6. Examples of directional jumping routes on snow by Vertagopus westerlundi during sunny weather. Each dot represents a starting point for a jump. The animals move upwards in the figure. The sinuous walking before each jump has been shown only in A. Two other species of Isotomidae also perform directional migration on snow: Isotoma hiemalis and Isotoma violacea. From Hågvar (2000).

trapped in depressions in the snow, for instance deep footprints of animals or even ski tracks, making it difficult to proceed in the same direction. In a trapped situation, it would be an advantage to try a new direction, if the animal cannot get out after some time. Field experiments showed that animals kept enclosed and trapped in small vials remembered their main direction when released after five and fifteen minutes, but usually chose a new direction after being trapped for half an hour or more (Hågvar, unpubl.).

\section{Migration behaviour of Isotomidae species}

The three species of Isotomidae mentioned previously were also able to perform directional, long-distance migration by continuous jumping on snow, using the sun as a guide (Hågvar, 2000). As in H. socialis, different individuals were often witnessed jumping in varying directions. Density of these species on snow was usually low, less than one animal per $\mathrm{m}^{2}$. Behaviour of Isoto-

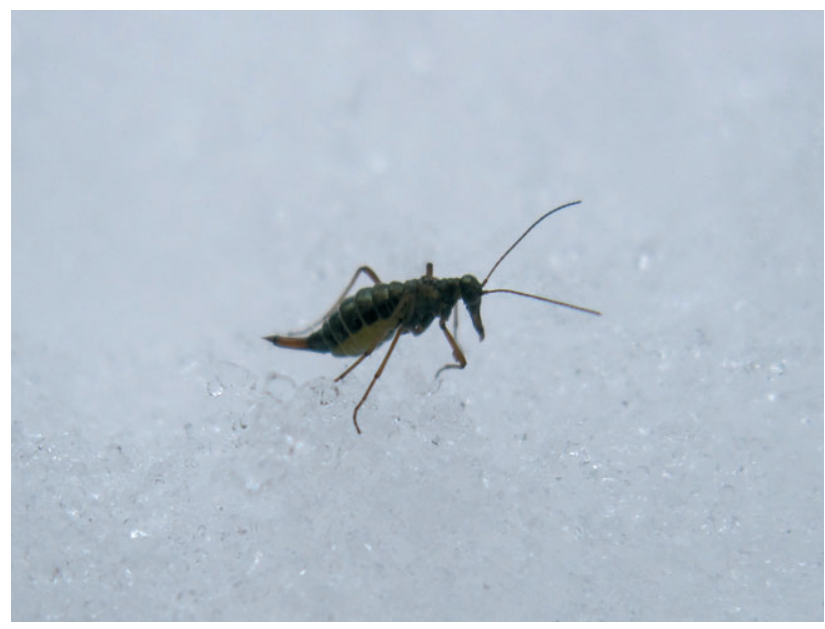

Fig. 7. A female of the genus Boreus (Mecoptera), that is famous for being active on snow. Photo: S. Hågvar.

midae deviated somewhat from $H$. socialis (Fig. 6). Instead of rotating on the spot after landing they usually made a sinuous walk for a few $\mathrm{cm}$ in approximately the correct direction, until they finally decided on jumping. The greatest recorded migration distances per minute were $22 \mathrm{~cm}$ in $V$. westerlundi, $50 \mathrm{~cm}$ in $I$. violacea, and $120 \mathrm{~cm}$ in $I$. hiemalis. The last mentioned migration rate, which corresponds to $70 \mathrm{~m}$ per hour, was observed during a mass migration on wet snow on 11 January 1998 in a coniferous forest near Oslo. At least five million individuals of $I$. hiemalis, at a density of about 5000 animals per $\mathrm{m}^{2}$, filled a $5 \mathrm{~m}$ wide snow-covered forest road, over a length of about $200 \mathrm{~m}$. All animals jumped in the same direction, following the road. During this intense migration, animals did not walk between the jumps, but rotated on the spot for about four seconds to decide the direction of the next jump. Since there was no visible sun, only patches of blue sky, the animals may either have used polarized light or simply the light, open forest road for navigation. Hågvar (2000) assumed that this mass migration was triggered by water logging of the ground in a nearby habitat due to some mild days with heavy snow melt. This phenomenon illustrates the ability of $I$. hiemalis to use the winter for controlled displacement of a large population, probably to more optimal habitats. In Finland, I. hiemalis has been found on snow down to $-3^{\circ} \mathrm{C}$ (Tahvonen, 1942). In Switzerland, Block \& Zettel (1980) observed it active on snow down to $-6^{\circ} \mathrm{C}$ and showed that juveniles could be supercooled to $\mathrm{ca}-19^{\circ} \mathrm{C}$ and adults to $\mathrm{ca}-13^{\circ} \mathrm{C}$.

Populations of $V$. westerlundi and $V$. sarekensis (Wahlgren) have also been shown to migrate slowly on snowfree ground in alpine habitats (Leinaas \& Fjellberg, 1985). While $V$. westerlundi headed towards tall, dry lichen-covered stones which they colonized, $V$. sarekensis remained on the ground and navigated by keeping a constant angle to the sun. 


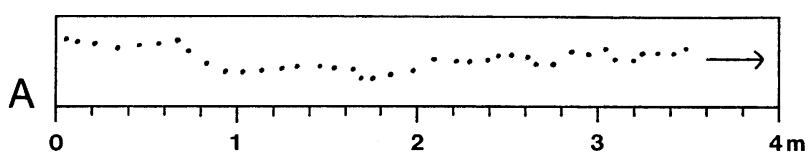

B
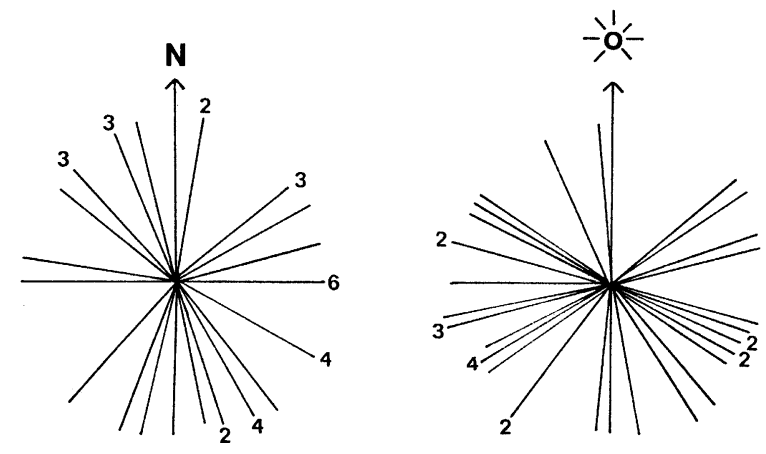

Fig. 8. Migration of Boreus westwoodi on snow. A - Example of directional migration in a female. Each dot represents a starting point of a jump. The next $3.5 \mathrm{~m}$ was passed in a still more direct line. $\mathrm{B}-$ Animals jump in different directions, both relative to the cardinal (compass) direction and to the position of the sun. From Hågvar (2001).

\section{MECOPTERA: GENUS BOREUS}

\section{Phenology and cold tolerance}

Species of the wingless, holarctic genus Boreus Latreille (Fig. 7) are famous for their activity on snow. Two species occur in Fennoscandia: Boreus westwoodi Hagen and Boreus hyemalis (L.). Larvae develop in the soil among mosses, and imagos hatch in autumn before a snow layer is established. Both larvae (Withycombe, 1922) and adults (Fraser, 1943; Strübing, 1950; Svensson, 1966) eat mosses. Only males can be identified at the present stage of taxonomical knowledge, but field studies indicate similar ecology of the two species (Hågvar, 2001). Adults can be observed on snow throughout the winter, but only on mild days with temperatures around or slightly above $0^{\circ} \mathrm{C}$ (Svensson, 1966, 1972; Fjellberg \& Greve, 1968; Sømme \& Østbye, 1969; Hågvar, 2001). This implies that Boreus is observed mainly during the last, milder period of the winter, or in early winter on the first, often moist, snow layers. During most of the winter, the animals stay in the subnivean environment, but periodically migrate between the subnivean and supranivean environments via vertical air channels along vegetation penetrating the snow.

According to Herter (1953), the preferred temperature of $B$. westwoodi is $4^{\circ} \mathrm{C}$ and of $B$. hyemalis $10^{\circ} \mathrm{C}$. Sømme \& Østbye (1969) found that both species could supercool their body fluids down to temperatures between -5 and $-6.5^{\circ} \mathrm{C}$, and be active in a supercooled state close to these temperatures. Mean chill-coma temperatures were $-4.1^{\circ} \mathrm{C}$ for $B$. hyemalis and $-5.5^{\circ} \mathrm{C}$ for $B$. westwoodi. Svensson (1966) observed how a $B$. westwoodi male on snow was just able to escape slowly below a spruce tree at an air temperature of $-5.5^{\circ} \mathrm{C}$.

In southern Norway, ovary studies of Boreus sp. showed that eggs are laid throughout the snow-covered period, from October to April (Hågvar, 2001). A primary batch of 10-20 eggs are laid during the first months, but around mid-winter the ovaries start to refill. In $B$. hyemalis, Steiner (1937) counted about 20 oocytes in each of 8 ovarioles per ovarium, indicating a maximum capacity of 320 eggs per female. According to laboratory studies, eggs are laid in moss, only 1-2 at a time (Withycombe, 1922; Strübing, 1950; Svensson, 1966; Cooper, 1974). This is in accordance with a long egg-laying period.

\section{The use of snow surface}

Courtin et al. (1984) showed that the North American species Boreus brumalis Fitch absorbed radiation from the sun under clear sky conditions. While the temperature at the snow surface was between 0 and $1^{\circ} \mathrm{C}$, the internal body temperature was raised to between 5 and $9^{\circ} \mathrm{C}$. In southern Norway, two thirds of the Boreus observations were made in overcast conditions (Hågvar, 2001). This may be due to danger of being active during sunny weather: Under clear sky the temperature may fall so rapidly during the evening that the animals may be unable to escape into the subnivean space in due time, and freeze to death. Cloudy conditions, on the other hand, ensure more stable temperatures. However, especially during late winter with temperatures well above zero, Boreus can be very active on snow in bright sunshine or in partly sunny weather (Hågvar, 2001). The increased body temperature is obviously an advantage both for the ability to move and for maturing new eggs in late winter.

Being wingless, the smooth snow surface represents a perfect arena for dispersal. By continuous jumping, $B$. westwoodi can move up to $1.2 \mathrm{~m}$ per minute, usually around half a meter. Moreover, each animal is able to keep a constant direction. As shown in Fig. 8, different individuals choose different directions (Hågvar, 2001).

Copulation has been observed a few times on snow (Hågvar, 2001). Copulation probably occurs mainly on bare ground shortly after hatching, as shown for $B$. hyemalis in Central Europe (Withycombe, 1922; Steiner; 1937; Strübing, 1950). However, the presence of well-fed males throughout the winter may indicate continued copulation below snow. Observations in culture have shown that copulation in Boreus takes a long time, up to two days (e.g. Sauer, 1966). The reduced motility of a copulating pair may make copulation on snow hazardous if temperature drops.

\section{DIPTERA: GENUS CHIONEA}

\section{Phenology and cold tolerance}

Three species of the genus Chionea Dalman have been recorded within Fennoscandia, but with different distribution patterns: $C$. araneoides Dalman, C. crassipes Boheman and $C$. lutescens Lundström (Oosterbroek \& Reusch, 2008). In southern Norway, C. araneoides has been closely studied, both concerning cold hardiness (Sømme \& Østbye, 1969), occurrence and behaviour on snow (Hågvar, 1971), and phenology of egg-laying (Hågvar, 1976a). Conclusions from these studies are as follows. The species has been observed on snow from 


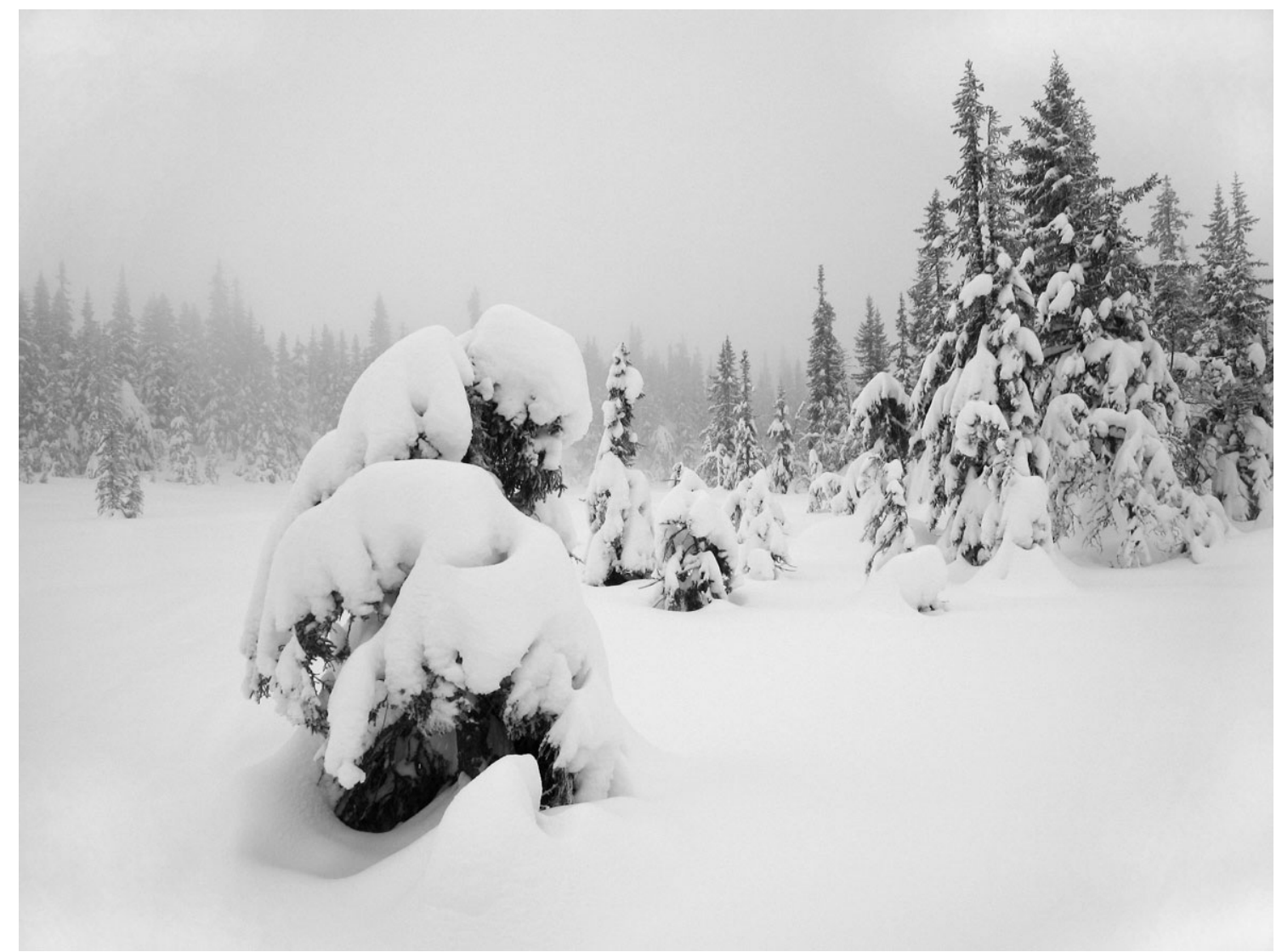

Fig. 9. A calm, overcast and partly foggy winter day in mid-South Norway. Such stable weather conditions are favoured by Chionea araneoides for migration on snow. Photo: S. Hågvar.

November to March. However, the main activity period on snow is during the coldest, middle part of the winter, with the majority of observations in January. Animals were active at temperatures between +1 and $-6^{\circ} \mathrm{C}$, with highest density (up to 9 per $1000 \mathrm{~m}^{2}$ ) around $-4.5^{\circ} \mathrm{C}$. The freezing temperature of the body fluid around $-0.7^{\circ} \mathrm{C}$ means that activity on snow usually is in a supercooled state. Since their chill-coma temperature is between -5 and $-6^{\circ} \mathrm{C}$, and they die at around $-7.5^{\circ} \mathrm{C}$, Chionea is balancing on the edge of their survival. In Finland, Nuorteva (1951) observed C. crassipes active on snow at $-6.8^{\circ} \mathrm{C}$. Wojtusiak (1950) found that Chionea-sp. preferred temperatures around $-3^{\circ} \mathrm{C}$. The animals are obviously vulnerable to even small drops in temperature. Therefore, they are typically only present on snow during very stable temperature conditions, i.e. in calm, cloudy weather, often during or just after a snowfall (Fig. 9). Wind is clearly a negative factor for Chionea.

Like in Boreus, eggs are laid during the snow-covered period. However, the phenology of egg-laying is different. Chionea imagines probably do not eat and they cannot refill the ovaries. Due to a limited life span, egg laying cannot wait, and most eggs are laid during the cold mid-winter (Hågvar, 1976a, Fig. 10). Since dissected females might contain any number of eggs between zero and their maximum capacity, only few eggs are laid at a time, and eggs from one female may be spread over many sites. The larvae develop in soil.

\section{Using the snow surface}

The long legs and tarsi make walking on even coarse snow an easy task. Most animals walk continuously and in a rather constant direction. Walking speed up to $0.5 \mathrm{~m}$ per minute has been observed at $-5.5^{\circ} \mathrm{C}$, and up to $0.8 \mathrm{~m}$ per minute at $-4.2^{\circ} \mathrm{C}$ (Hågvar, unpubl., temperatures measured at the snow surface). In cold weather when there is a need to find a vertical channel to subnivean conditions, $C$. araneoides has twice been observed to head against a large spruce tree with many branches penetrating the snow (Hågvar, unpubl.).

If the sexes of $C$. araneoides are put together on snow they often mate spontaneously (Fig. 11). Surprisingly, mating pairs have very rarely been observed on snow. This may be due to the rather thin population on snow, and perhaps copulations occurring during late autumn on snow-free ground, or below snow. Chionea has been trapped in subnivean pitfall traps (Wiger, pers. comm., Hågvar \& Hågvar, unpubl.)

\section{DIPTERA, TRICHOCERIDAE: GENUS TRICHOCERA}

\section{Phenology and cold tolerance}

Trichocera Meigen is a holarctic, cold-adapted genus comprising 108 species (Krzeminska, 2009), of which 24 have been recorded in Fennoscandia (Hågvar \& Krzeminska, 2007; Fauna Europaea, 2009). They are called winter gnats or winter crane flies since they can be active at very low temperatures, even after frost periods. Swarming 


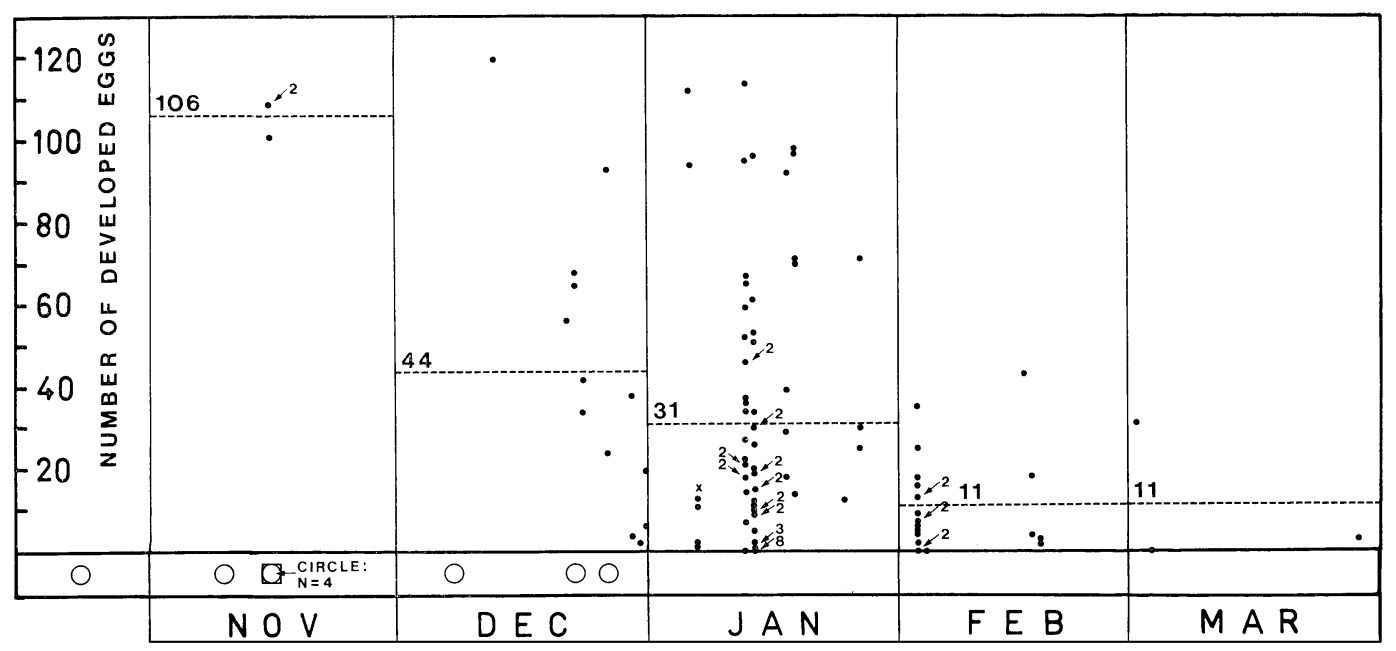

Fig. 10. The mean number of ripe eggs per female of Chionea araneoides is reduced from November to March (horizontal, stippled lines). Most eggs are laid during mid-winter, in December and January. Ovaries are not refilled. Circles indicate the presence of females with only partly developed eggs in early winter. From Hågvar (1976a).

occurs at certain combinations of temperature, humidity and light, and is arrested by wind (Dahl, 1965, 1969). These large insects may be observed on snow, sometimes even flying in snow-covered areas (Dahl, 1974; Hågvar \& Krzeminska, 2007). Larvae are terrestrial, developing in moist habitats among various decaying organic matter. In a supercooled state they are able to move normally down to $-4^{\circ} \mathrm{C}$, but their winter activity is periodically arrested by frost in snow-free areas (Dahl, 1969, 1970). Their ability to grow at low temperatures, combined with a summer or winter quiescence in some species, makes the duration of the larval stages very flexible. Therefore, the life cycle and phenology of a given species may differ considerably between climatic regions (Dahl, 1969, 1970). While swarming in subarctic/arctic regions takes place in the cool, short summer, swarming in the Fennoscandian boreal and subboreal regions is typically highest during autumn (Dahl, 1970, 1974).

In southern Norway, fifteen Trichocera species have been encountered on snow in different boreal forest

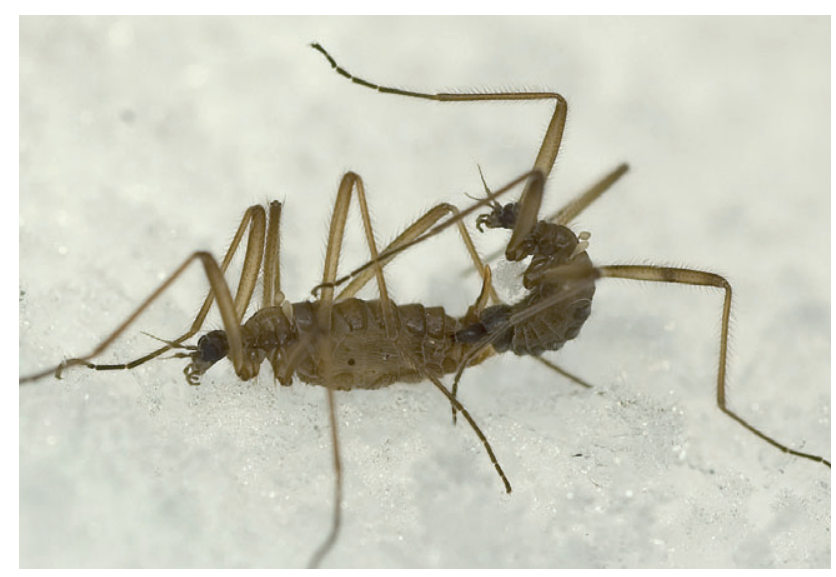

Fig. 11. A pair of Chionea araneoides copulating on snow. This is rarely observed, but if the sexes are brought together on snow, they often mate spontaneously. Photo: H. Elven. localities. Winter gnats were present on snow during all winter months from October to April, with up to eleven species in December. The insects were collected at temperatures close to $0^{\circ} \mathrm{C}$ and mainly in calm, overcast weather with a high air humidity. Flying individuals of some species were observed between 1 and $3^{\circ} \mathrm{C}$ (Hågvar \& Krzeminska, 2007). In Finland, Tahvonen (1942) found $T$. regelationis (L.) on snow at $-2^{\circ} \mathrm{C}$, and $T$. hiemalis (De Geer) at $-3^{\circ} \mathrm{C}$. According to Dahl (1969), supercooled males of $T$. saltator (Harris) and $T$. regelationis (Fig. 12) were able to walk and attempted to fly in temperatures at least down to $-4^{\circ} \mathrm{C}$.

During winter in Norwegian boreal forest, females of several Trichocera species collected on snow had their abdomen more or less filled with eggs (Hågvar \& Krzeminska, 2007). Large variation in egg numbers between females of the same species indicated that egg laying is going on during the winter, and that eggs are deposited in portions. Females of several species have a capacity of 200-300 eggs. If female survival is good due to the snow cover, a long egg-laying period covering different sites seems possible for each individual. Since larvae develop in soil, and there are indications that egg laying occurs in darkness (Laurence, 1956; Dahl, 1969), egg-laying below snow seems reasonable. Most data was collected from $T$. implicata Dahl, and a trend showing reduced number of remaining eggs in females from November to February indicates stepwise egg-laying pattern during this period (Hågvar \& Krzeminska, 2007).

\section{Taking advantage of snow}

Phenology of winter gnats is affected by the duration and thickness of snow cover (Dahl, 1969, 1970; Hågvar \& Krzeminska, 2007). In southernmost Sweden, representing the subboreal region, there is rarely a continuous snow cover during the winter. There are therefore few microhabitats where insects may escape during cold spells, and the adults are easily killed by frost. However, in the more northern boreal forest belt, a snow cover of 


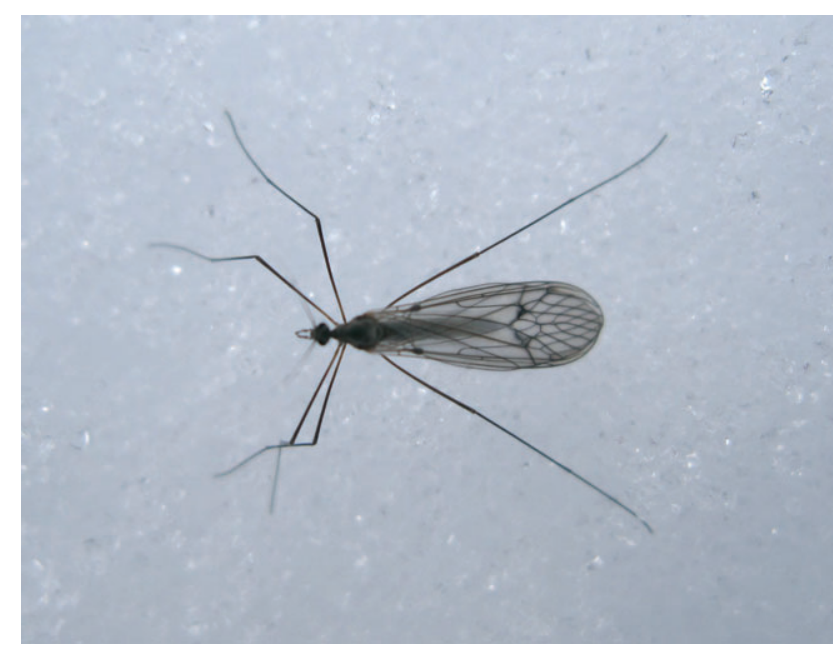

Fig. 12. Several species of winter gnats (Trichoceridae) can be encountered on snow in Fennoscandia. This is the large species Trichocera regelationis. Photo: S. Hågvar.

$20 \mathrm{~cm}$ or more stabilizes the temperature below snow around $0^{\circ} \mathrm{C}$.

Both larvae and adult winter gnats are able to move actively at this subnivean temperature, and this, in combination with high air moisture, further increases the life span of adults. Pitfall trapping below snow in boreal forests of Finland, Sweden and Norway has demonstrated subnivean activity of Trichocera species (Viramo, pers. comm.; Dahl, 1974; Hågvar \& Hågvar, unpubl.). Vertical migration between the subnivean and supranivean environment is possible along air channels that gradually develop along tree stems and other vegetation protruding through the snow cover. Animals may climb up to the snow surface on mild days, be active in the snow-covered landscape and retreat to subnivean conditions when temperature drops.

The presence of imagines on snow throughout the long boreal winter has two possible explanations: Either prolonged survival of an autumn generation, or delayed emergence, e.g. hatching below snow. For certain species that are only present in early winter, the first explanation is adequate. However, the occurrence of apparently freshly emerged individuals with completely filled ovaries or with undeveloped eggs during mid and late winter supports the possibility of winter hatching in some species (Hågvar \& Krzeminska, 2007).

In conclusion, the insulating and moisture-preserving effect of snow may allow Trichocera species to be active not only far North, but also throughout the winter.

\section{DIPTERA: BRACHYCERA}

\section{Phenology and cold tolerance}

During a long-term study in south Norway, as many as 44 species of flies were recorded live on snow, mainly in coniferous forests (Hågvar \& Greve, 2003). Flies usually appeared in calm, overcast weather, at temperatures around $0^{\circ} \mathrm{C}$ (between -4 and $5^{\circ} \mathrm{C}$ ). The snow surface was often moist and it could be foggy or snowing, so a high relative humidity was typical. The families Heleomyzidae

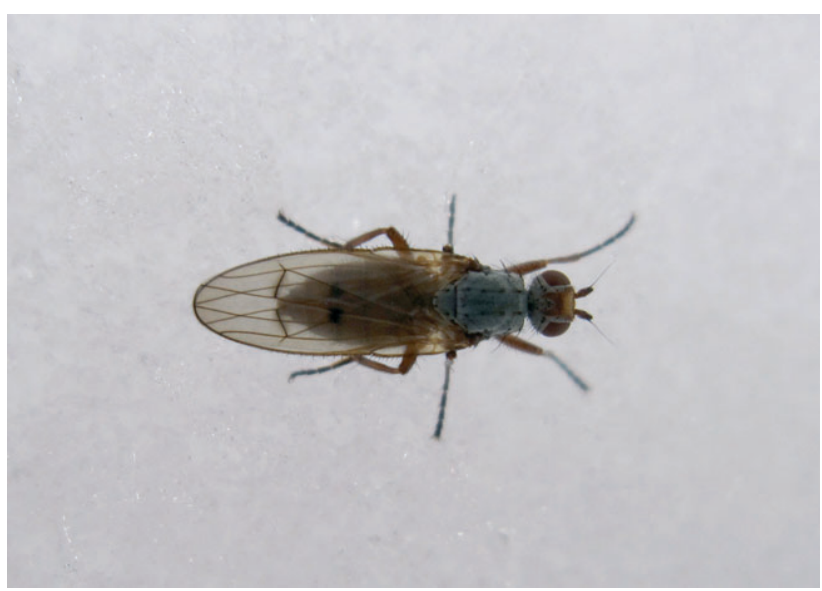

Fig. 13. Several species of Heleomyzidae regularly occur on snow. Most common of them is Scoliocentra nigrinervis. Photo: S. Hågvar.

and Sphaeroceridae dominated, with 13 and 10 species, respectively. Several species occurred regularly on snow throughout the winter, for instance Scoliocentra nigrinervis (Wahlgren) (Heleomyzidae) which was most abundant, and further, Crumomyia notabilis (Collin) (Sphaeroceridae), Pachycerina seticornis (Fallén) (Lauxaniidae), and Chromatomyia fuscula (Zetterstedt) (Agromyzidae). Dissections revealed fully developed eggs in five species, and two Anthomyiidae species of the genus Hylemya Robineau-Desvoidy contained rather large larvae, but deposition of eggs or larvae during winter could not be demonstrated in any species.

Scoliocentra nigrinervis (Fig. 13) is a well-known winter active "snow fly". In Sweden, Svensson (1966) observed it on snow down to $-8^{\circ} \mathrm{C}$, and even during night. In Finland, Nuorteva (1951) found it active on snow at $-12.7^{\circ} \mathrm{C}$. This cold-tolerant species can survive about $-16^{\circ} \mathrm{C}$ by supercooling without using glycerol (Sømme \& Østbye, 1969). Females carry around 100 ripe eggs throughout the winter, indicating egg laying after snow melt (Hågvar \& Greve, 2003). Copulation on snow has been observed only once; in March at $0^{\circ} \mathrm{C}$ (leg. A. Fjellberg).

Among Sphaeroceridae, Crumomyia notabilis is the most common winter active species in southern Norway. It can be observed on snow throughout the winter at temperatures down to $-1^{\circ} \mathrm{C}$. Females carry $20-50$ ripe eggs, which are probably laid after the snow melts (Hågvar \& Greve, 2003). Hackman (1963) also found the species on snow in Finland, and even trapped it in burrows of small rodents during winter.

Hågvar \& Greve (2003) noted that a large number of the recorded species, especially among Heleomyzidae and Sphaeroceridae, are saprophagous in a broad sense. They presented the hypothesis that cold-adapted, saprophagous flies with eggs or larvae ready for deposition have an advantage during snow melt in colonizing suitable substrates. During winter, forests may accumulate excrements and dead bodies like a big freezer, and these substrates are made available during a short time-period 


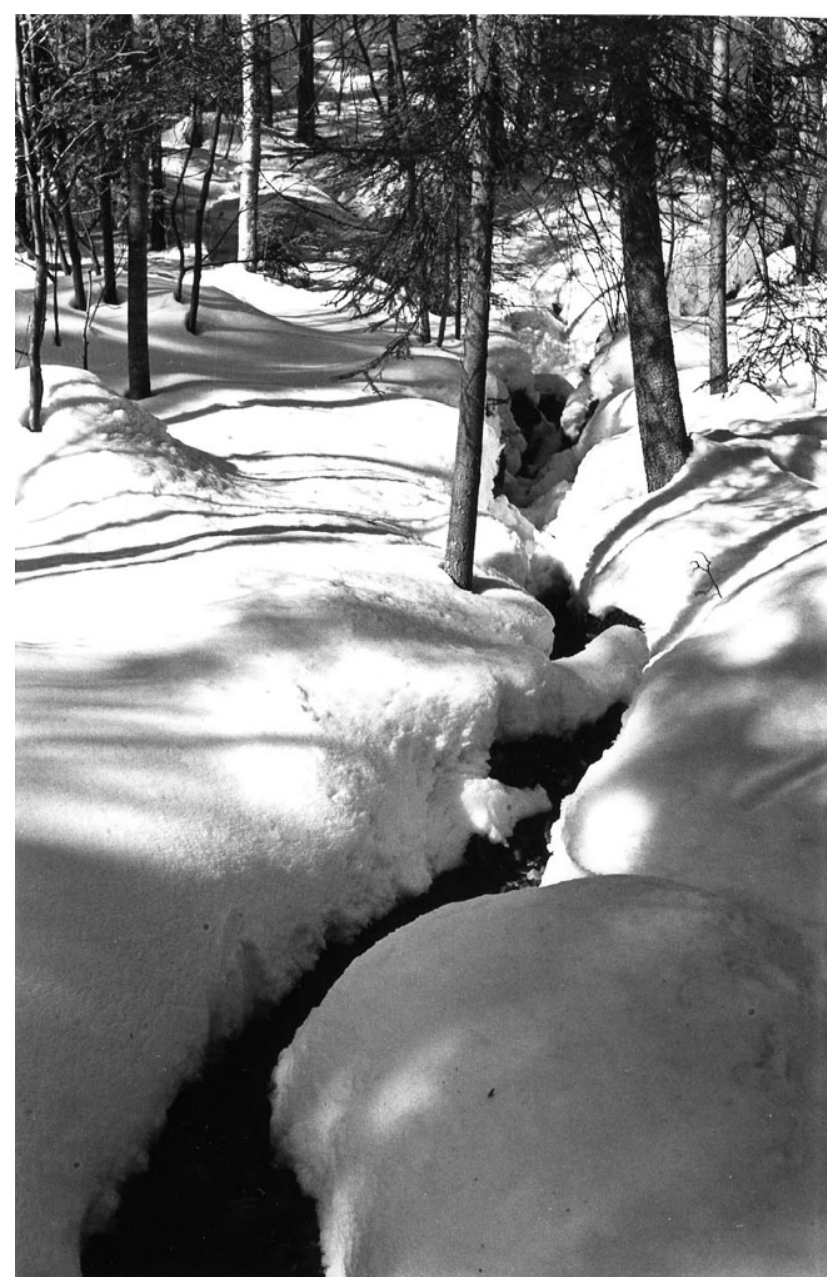

Fig. 14. A small, winter-open brook in mixed forest near Oslo. Several winter active Chironomidae hatched here. Photo: S. Hågvar.

at snow melt. Flies ready for egg laying may colonize these resources rapidly, outcompeting for instance saprophagous beetles. According to Czerny (1927), Heleomyzidae often develop in excrements. The presence on snow may simply reflect a continuous awareness for suitable substrates at low temperatures.

The cold tolerance of many Heleomyzidae and Sphaeroceridae species has also been documented by pitfall trapping during winter in German grassland (Bährmann, 1996). Many species of Heleomyzidae that are common far north are restricted to high altitude, cool mountain areas in middle Europe (Papp, 1981), and several Sphaeroceridae have been collected on glaciers in Italian alps (Munari et al., 1997).

\section{DIPTERA: CHIRONOMIDAE}

\section{Phenology and cold tolerance}

Some species of Chironomidae are able to reproduce during the winter. In southern Norway, Hågvar \& Østbye (1973) collected four species on snow: Chaetocladius laminatus Brundin, Diamesa permacer (Walker), D. bohemani (Goetghebuer) and Pseudodiamesa branickii (Nowicki). The observations were made from lowland to alpine habitats, mostly at temperatures close to $0^{\circ} \mathrm{C}$. Usually, the chironomids were active on snow close to open brooks or water holes from which they had hatched (Fig. 14), but some observations far from open water indicated dispersal by active flying or by wind. In calm, cloudy weather, D. permacer was seen flying at $-1^{\circ} \mathrm{C}$, and $C$. laminatus at $0^{\circ} \mathrm{C}$. Diamesa permacer was capable of active movements on snow down to at least $-4.5^{\circ} \mathrm{C}$, survived at least $-13.5^{\circ} \mathrm{C}$ during night, but died when exposed to $-22.5^{\circ} \mathrm{C}$ for an hour.

Along the Strandaelvi river at Voss, western Norway, Jonsson \& Sandlund (1975) collected two other Diamesa species on snow: D. thienemanni Kieffer and D. latitarsis (Goetghebuer). The density of Chironomidae on snow close to the river bed was usually 5-10 individuals per $\mathrm{m}^{2}$. Flying and copulating specimens were observed at temperatures close to $0^{\circ} \mathrm{C}$, often in moist, overcast weather. Water temperature varied between 0 and $2^{\circ} \mathrm{C}$ at the sampling sites.

Hågvar \& Østbye (1973) noted that C. laminatus, D. bohemani and $P$. branickii also have been found as imagines during the autumn. They speculated whether two simultaneous generations existed, each using one year to fulfil their life cycle. D. thienemanni and D. latitarsis have two hatching periods, also emerging between June and October in Norway and Sweden (Jonsson \& Sandlund, 1975). These Chironomids therefore do not belong to the exclusively winter insects that reproduce only during the winter, but winter hatching is an annual phenomenon. At least $C$. laminatus and $D$. thienemanni appear to hatch throughout all winter months. Jonsson \& Sandlund (1975) considered a prolonged winter emergence as an advantage for a population hatching under extreme conditions since a simultaneous hatching makes the population vulnerable to unexpected low temperature.

\section{Using the snow surface}

All the above-mentioned species except $P$. branickii have been observed to use the snow surface for mating. Swarming behaviour seemed to be unnecessary, rather the insects were typically walking around. According to Oliver (1968) it is an advantage for arctic Chironomidae to be able to mate without swarming as flying might be impossible because of low temperature. Hågvar \& Østbye (1973) suggested that the smooth, white snow surface might be a good arena for these insects to discover the mate by sight during walking. For instance, specimens of $D$. permacer easily copulated without swarming at $-1^{\circ} \mathrm{C}$. Both sexes were very active on snow at this temperature; males were opening and closing their hypopygium. Jonsson \& Sandlund (1975), however, doubted that sexes achieved contact by sight.

\section{PLECOPTERA}

\section{Phenology and cold tolerance}

Certain stoneflies are active on snow during late winter in Fennoscandia, hatching from open cracks and holes in the ice cover of large and small rivers (Fig. 15). The two most common species with this phenology is Taeniop- 


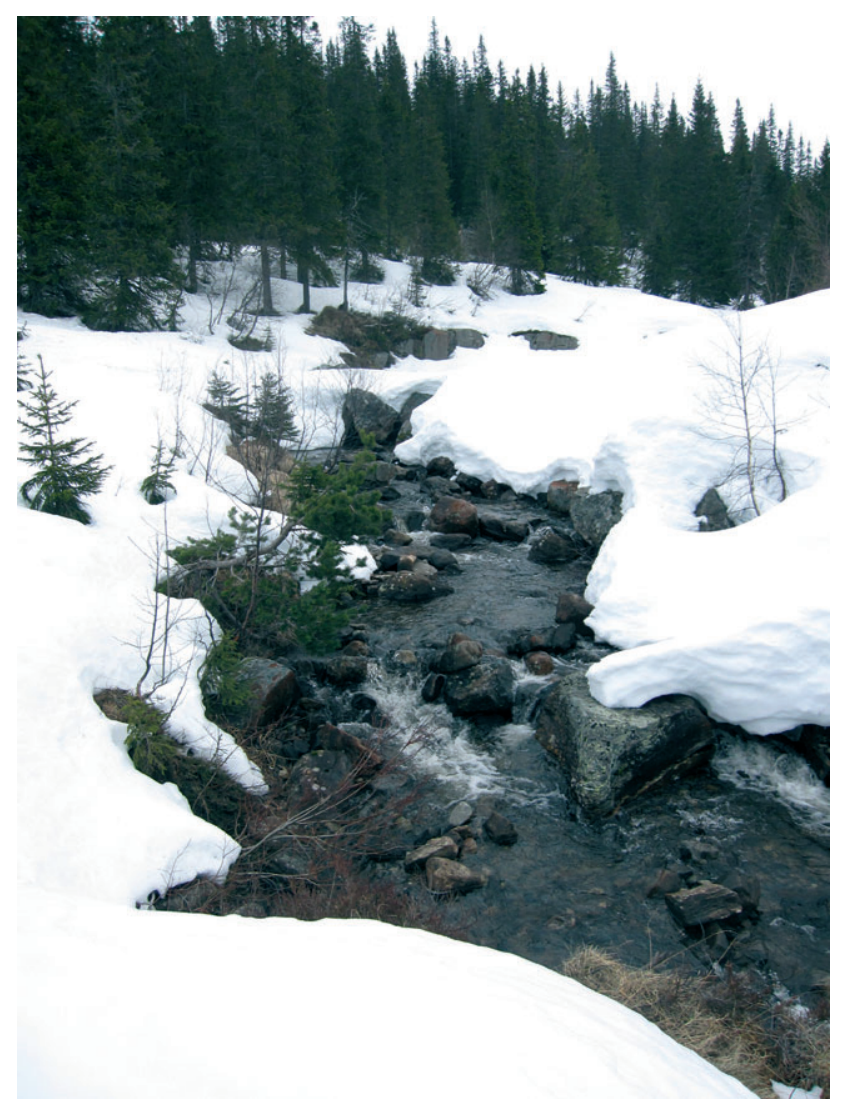

Fig. 15. An open river in a high altitude coniferous forest, central South Norway. High numbers of the large stonefly, Taeniopteryx nebulosa, hatch here in late winter, and walk around on snow. Photo: S. Hågvar.

teryx nebulosa (L.) and Capnia pygmaea (Zetterstedt), whose nymphs are able to develop in cold water during winter (Brinck, 1949; Ulfstrand, 1968; Lillehammer, 1971, 1988). C. pygmaea is used in a traditional fishing through ice in the large river Glåma in south Norway. Stoneflies are collected and poured into holes drilled in the ice to attract fish (Lillehammer, 1971). In snowcovered Northern Lapland, Koponen (1983) found $T$. nebulosa together with Capnia atra Morton near open rapids.

T. nebulosa (Fig. 16) is a large species with a body length up to $15 \mathrm{~mm}$. In streams of Swedish Lapland, Ulfstrand (1968) found that the nymphs were about halfgrown at the time of ice-cover during early winter, and the rest of the growth occurred below ice. Hatching time in Fennoscandia depends on when the ice cover starts to open, and varies from March to July depending on altitude and latitude (Lillehammer, 1988). According to Brinck (1949), females hatch with undeveloped eggs, but they eat lichens and green algae from trunks and twigs and are able to mature the eggs rather rapidly.

\section{Activity and behaviour on snow}

The activity and behaviour of T. nebulosa on snow was studied for several years by Hågvar (unpubl.) in a mountain forest area at Vegglifjell, Buskerud, about $800 \mathrm{~m}$ above sea level in central southern Norway. Hatching

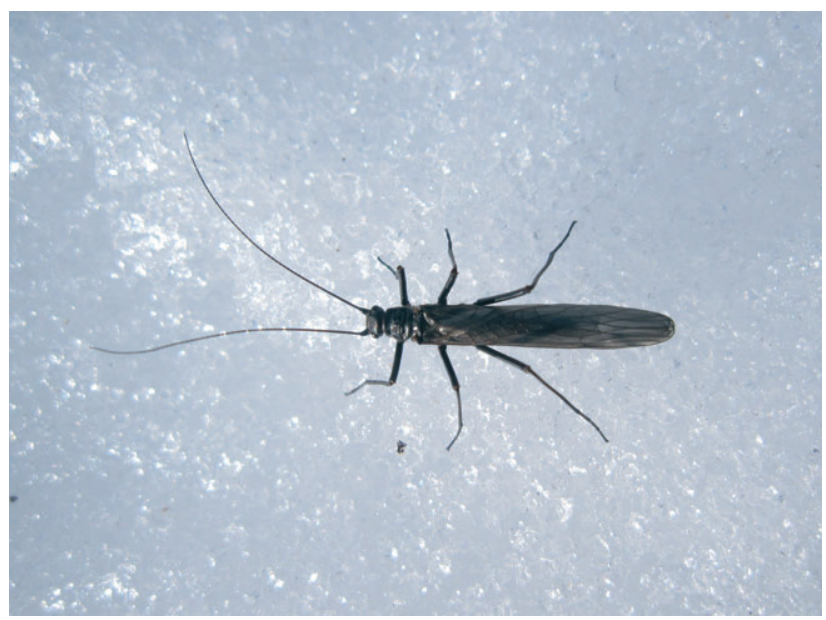

Fig. 16. The stonefly Taeniopteryx nebulosa walking on snow. Photo: S. Hågvar.

occurred in March or April when the snow cover was 0.5-2 m thick. Nymphs hatched on the ice and snow on the river bed, leaving their exuviae. Males dominated the early phase of hatching. It was confirmed that newly hatched females had undeveloped eggs. High numbers of adults were walking on the snow, often 20-35 m from the river, and up to $200 \mathrm{~m}$ away. None were seen to fly, mate, feed or deposit eggs, just walking on snow. The insects were typically walking uphill, which often meant away from the river. No clear upstream migration was observed. In overcast weather at $2^{\circ} \mathrm{C}$, walking speeds between 1 and $2.2 \mathrm{~m}$ per minute were observed. However, during frosty nights, all animals disappeared from the snow surface. Since beating in the vegetation did not reveal any animals, it was assumed that they had escaped towards the subnivean environment along air channels that were abundant along bushes protruding the snow. Even a later temperature rise to $10^{\circ} \mathrm{C}$ did not bring animals up to the snow surface. Perhaps they stay close to the ground for a long time, either waiting or finding something to eat. It is unknown whether this population waits until snow melt before egg-laying.

\section{ARANEAE}

\section{Phenology}

Many Fennoscandian spiders are cold tolerant and are more or less winter active, even in areas with little or only periodic snow cover (Aakra, 1998). Spiders active on snow are an annual phenomenon in boreal forests, with numerous species involved. In northern Finland, Huhta \& Viramo (1979) collected more than hundred species on snow, and further documentation there was done by Koponen (1983, 1989). Hågvar \& Aakra (2006) recorded 46 species on snow in southern Norway. Spiders occur on snow during all winter months, mainly at temperatures around or above $0^{\circ} \mathrm{C}$, but even down to $-7^{\circ} \mathrm{C}$. Most of the species belong to Linyphiidae. Typical species in both Norway and Finland are Bolephthyphantes index (Thorell), and Tenuiphantes cristatus (Menge) (Fig. 17). In northern Finland, also the linyphiids Macrargus rufus 


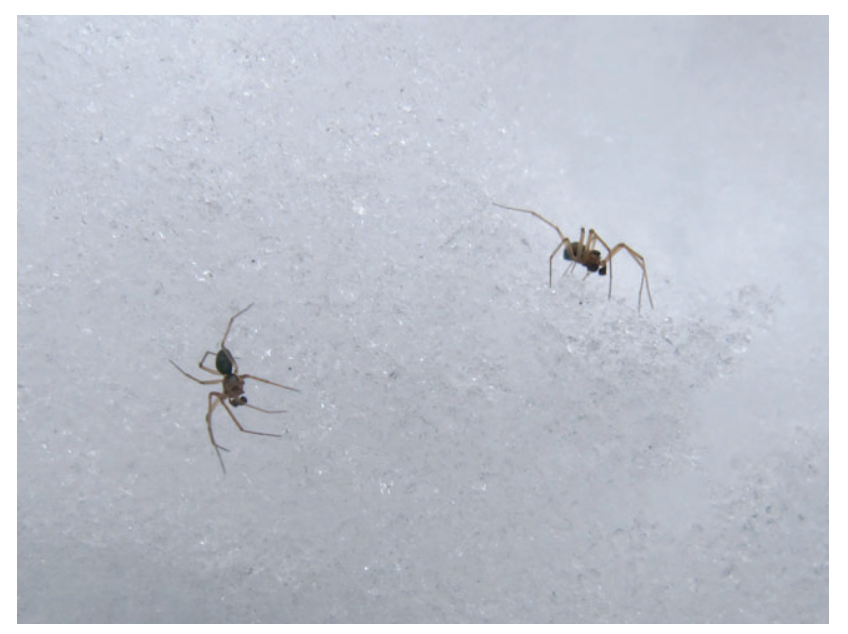

Fig. 17. More than a hundred species of spiders have been found on snow in Fennoscandia. The picture shows two males of Tenuiphantes cristatus (Menge, 1866), a common species on snow. Photo: S. Hågvar.

(Wider) and M. multesimus (O.P.-Cambridge), as well as the gnaphosid Gnaphosa intermedia Holm have been found abundant on snow (Huhta \& Viramo, 1979; Koponen, 1983, 1989). Comparisons with Finnish pitfalltrapping below snow (Koponen, 1976, 1989) and a Norwegian study of the spider fauna on spruce branches during winter (Hågvar \& Hågvar, 1975) showed that nearly all species colonise the snow surface from the subnivean air space. For most spiders, their occurrence on snow in mild weather may simply be a continuation of their normal subnivean activity. However, during very warm days in April, subadults of the genus Philodromus Walckenaer can start wind dispersal by sending out "flying threads" from trees and may land in large numbers on snow (Hågvar \& Aakra, 2006). From there, they probably seek snow-free patches.

\section{Spider webs on the snow surface}

Both in Finland and Norway, Bolephthyphantes index is common on snow during late winter (Hågvar, 1973; Huhta \& Viramo, 1979; Koponen, 1983, 1989; Hågvar \& Aakra, 2006). Cold tolerance and behaviour of this species was studied by Hågvar (1973) and Hågvar \& Aakra (2006). The thermal preferendum of $B$. index is around $4^{\circ} \mathrm{C}$, the spider is active in a supercooled state down to about $-9^{\circ} \mathrm{C}$, and survives above its supercooling point around $-15^{\circ} \mathrm{C}$ (Fig. 18). This cold-adapted spider con-

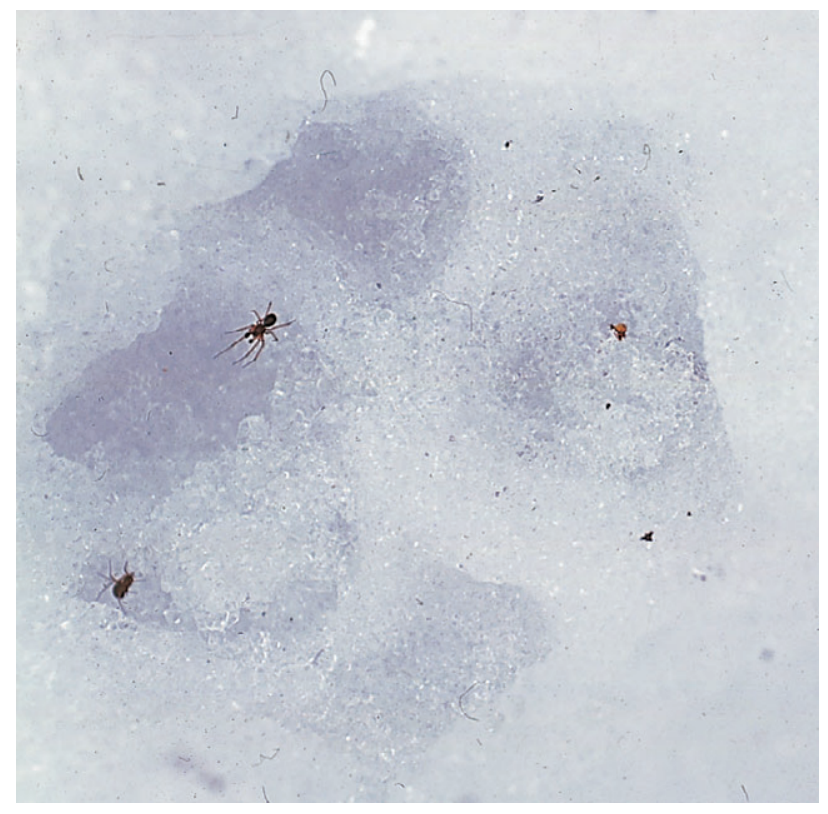

Fig. 19. A pair of Bolephthyphantes index sitting in a web constructed over a footprint of a fox. Migrating springtails are caught in the web. Photo: G. Hågvar.

structs horizontal webs over small depressions in the snow surface, for instance in footprints of animals (Fig. 19). Winter active springtails and even species of Psyllidae blown down from trees have been recorded in the webs. The diameter of the web is usually $3-5 \mathrm{~cm}$. One web was constructed across a ski track during less than an hour, in sunny weather at about $8^{\circ} \mathrm{C}$. In one case, a web was constructed at temperatures below $0^{\circ} \mathrm{C}$, and this animal was active in the web at $-5.5^{\circ} \mathrm{C}$. Copulation was observed in a web at $2^{\circ} \mathrm{C}$. Consumption of prey occurred both day and night. A physical characteristic for the sites with the highest density of $B$. index was a high number of stems and twigs penetrating the snow surface, creating many connections to the subnivean environment. These passages not only allow the species to reach the snow surface, but also ensures retreat possibilities if the snow surface temperature becomes too low. Up to one walking animal per $\mathrm{m}^{2}$ was observed at $0^{\circ} \mathrm{C}$, and the highest density of webs was about one per $2 \mathrm{~m}^{2}$ (Hågvar, 1973).

In Norway, Østbye (1966) found a specimen of Centromerus incilium (L. Koch) in a web with captured collembolans on snow. No such webs have been found later, but Huhta \& Viramo (1979) collected several individuals

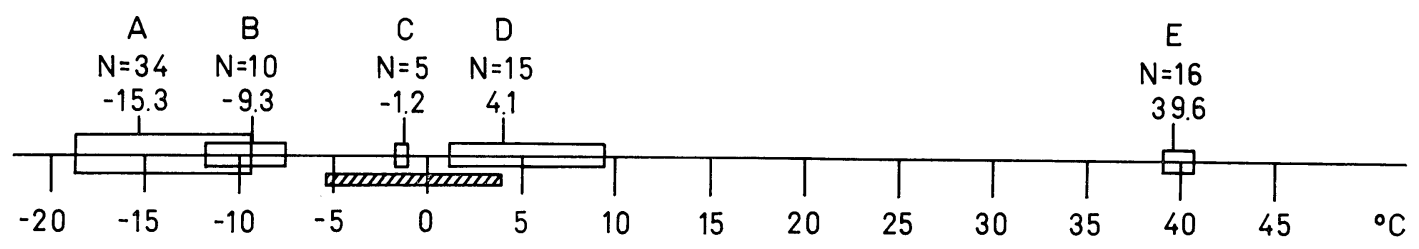

Fig. 18. Different reactions to temperature in the winter active spider Bolephthyphantes index. $\mathrm{A}=$ supercooling points, $\mathrm{B}=$ chillcoma temperatures, $\mathrm{C}=$ haemolymph freezing points, $\mathrm{D}=$ temperatures preferred, $\mathrm{E}=$ upper thermal paralysis. The range is indicated together with the mean value. $\mathrm{N}=$ number of specimens. Hatched block: Temperature range during field observations. From Hågvar (1973). 


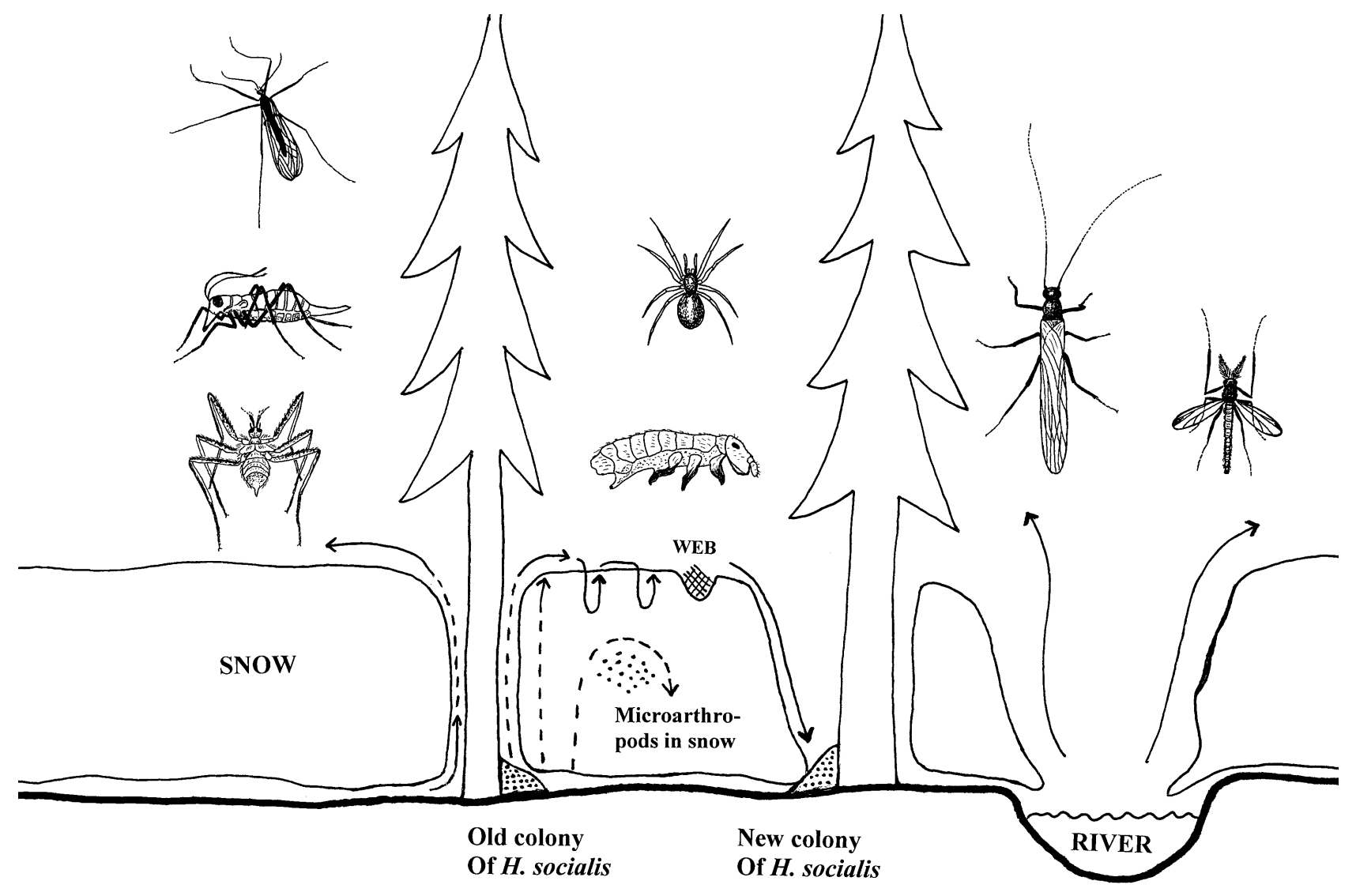

Fig. 20. Schematic illustration of how some arthropods use snow as a substrate. To the left and from the top: Trichocera (Diptera), Boreus (Mecoptera), and Chionea (Diptera) climb to the snow surface during mild weather and retract to the subnivean environment in cold weather. In the middle: Several microarthropods stay within the snow pack, but the springtail Hypogastrura socialis enters the snow surface and performs mass migrations in mild, sunny weather. At low temperatures, they retract vertically into the snow layers, waiting for another mild day. New colonies are formed near the end of the winter. The spider Bolephthyphantes index catches springtails in webs on the snow. To the right: Certain species of Plecoptera and Chironomidae hatch from open rivers and brooks in winter and are active on snow.

of this species on snow during early winter in northern Finland and considered the species to be typically winter active.

\section{DISCUSSION AND CONCLUSIONS}

\section{"Snow arthropods": a holarctic, or southern, alpine phenomenon}

Arthropod activity below, in and on snow takes place throughout the holarctic, as well as in alpine areas further south. Typical taxa like Trichoceridae, Boreus, Chionea, and Diamesa have a holarctic distribution (Dahl, 1970; Svensson, 1972; Vanin \& Masutti, 2008; Bouchard \& Ferrington, 2009). In Poland, Soszynska (2004) found a rich supranivean Diptera fauna in the Lodz Upland. In middle Europe, many Heleomyzidae (Diptera) only occur in mountain areas (Papp, 1981). In the Italian Alps, a large number of spiders are active on and under snow (Vanin \& Turchetto, 2007), several species of Sphaeroceridae (Diptera) have been found on ice and snow (Munari et al., 1997), and three species of Chionea occur (Vanin \& Masutti, 2008). Block \& Zettel (1980) and Zettel (1984b) reported on winter active springtails in alpine Switzerland. A general overview of snow arthropods was given by Aitchison (2001).

\section{Taking advantage of snow: Different solutions and adaptations}

Arthropods from widely different taxa are able to use the snow as substrate for their winter activity. However, the way they use the snow may differ, and "snow arthropods" may be in different phases of their life cycle. Hence there are different ways in which invertebrates take advantage of snow (Fig. 20). Each solution depends on certain adaptations, which may be morphological, physiological or behavioural.

Advantage 1: Increased winter survival by staying within snow

Leinaas (1981a, 1983c) assumed that microarthropods staying within snow increased their survival during the non-reproductive phase by avoiding harmful water logging or ice formation along the ground. Reduced predation may also be an explanation (see below). The upward migration reflects a behavioural adaptation, and physiologically these animals are able to move within snow even at temperatures slightly below zero. Because of their small size, these animals are morphologically pre-adapted to penetrate the small spaces between snow and ice crystals. 
Advantage 2: Improved dispersion on the snow surface

For several wingless arthropods, the smooth snow surface represents a favourable arena for migration and dispersion. This arena is rather free of obstacles, the air humidity is high and predation risk is close to zero (see separate point below). Migration rates between a half and one meter per minute are often achieved.

Migration on snow illustrates adaptations in morphology, physiology and behaviour. Concerning morphology, H. socialis is cyclomorphic: winter animals with a new cuticula have stronger spines on the furca, facilitating jumping on slippery snow and ice (Leinaas, 1981b). Their sticky, eversible anal sacks which stop rotation at each landing (Hågvar, 2000), can be regarded as a preadaptation for winter migration, since this structure is found in many related species (Leinaas, 1988). Absence of wings in Chionea and Boreus is an adaptation to low temperatures where flight is difficult or impossible. The very long tarsi and the lateral insertion of the legs in Chionea allow a steady walking on snow, both on very loose snow resulting from large snow crystals, and on rugged snow surfaces resulting from wind erosion.

Physiologically, species migrating on snow are highly cold tolerant. For instance, Chionea migrates efficiently in a supercooled state and behaves normally down to about $-5^{\circ} \mathrm{C}$.

Behavioural adaptations in connection with migration may be rather advanced. The ability to navigate on snow has probably developed independently in springtails and Boreus, and even within different springtail families. Jumping animals have the common problem of reconstructing the direction after each uncontrolled landing. In both Collembola and Mecoptera, the jumping ability is originally an escape mechanism from approaching predators, and an escape jump is often followed by a nonmoving phase. Independently, jumping as an escape mechanism has developed into a migration mechanism.

\section{Advantage 3: Avoidance of predation}

Avoidance of predation may be a part of both advantages, 1 and 2. Migration of surface-active microarthropods up into the snow layers prevents a possible predation pressure from active, subnivean predators. For instance, several species of spiders and predatory beetles (including larvae) are regularly active below snow, as illustrated by pitfall trapping in Sweden (Näsmark, 1964), Finland (Koponen, 1976), and Norway (Hågvar \& Hågvar, unpubl.). Apart from the ability of the spider $B$. index to capture a minuscule fraction of springtails on snow, predation on wingless arthropods migrating on snow has never been observed by the author throughout four decades of field work. The combination of a smooth surface, easy to move on, and the absence of predators may be a clue to adaptation for snow surface migration.

\section{Advantage 4: Using the snow surface for feeding}

The spider $B$. index is the only arthropod species that uses the snow surface for feeding. Besides being physiologically cold tolerant, its ability to construct webs on snow is primarily a behavioural adaptation.
Advantage 5: Winter activity makes early start possible in spring

Winter activity may allow for an early start of egg laying or egg hatching, and this may have a competitive benefit. New colonies of $H$. socialis are established in early, snow-free patches, where the colony performs an early, synchronous egg-laying (Leinaas, 1983b). Early feeding and mating on snow in the spider $B$. index also indicates early egg-laying. The winter active flies, $S$. nigrinervis and $C$. notabilis, which carry ripe eggs throughout the winter, are assumed to outcompete, for instance beetles, when common resources, such as carrion or dung, are released from nature's big "freezer" at snow melt. Finally, eggs of Chionea and Boreus, laid in the subnivean space during winter, can start developing in soil as soon as spring temperature allows.

\section{Advantage 6: Copulation is possible on snow}

Chironomids hatching from open water use the snow surface for contact and copulation, often without flying. The spider $B$. index copulates in webs on snow. In rare cases, Chionea and Boreus have also been observed copulating on snow.

Advantage 7: An insulating snow cover allows flexible Trichoceridae to live far north

Several species of Trichoceridae manage well even in high arctic conditions, being able to use even short, snowfree "summers" for hatching, swarming and egg-laying. Larvae take advantage of an insulating snow cover and show a very flexible development. They are cold tolerant, able to use unpredictable mild periods for feeding and growth, and prolong their developmental time according to local, harsh conditions. Pupation and hatching occur when temperature allows. Thus a given species can show quite different life-cycle patterns in different climatic zones. A flexible life cycle, together with a highly developed cold tolerance, is the key for the success of Trichoceridae in boreal and arctic conditions. In boreal forests, the snow cover allows for a prolonged adult survival and winter activity.

Table 1 sums up the purpose of winter activity, as well as behaviour, phenology, weather preference and reactions to temperature in four wingless arthropods which actively use the snow surface during their life cycle.

\section{Grouping of "snow arthropods"}

Arthropods occurring in or on snow span from highly specialized species to random visitors. According to current knowledge, they are not easy to categorize, and may represent more or less a continuum in adaptations to winter life. In the following section, various ways of ecological grouping of snow arthropod taxa will be discussed.

\section{Grouping according to type of advantage}

The seven advantages listed illustrate various ways of making the use of snow. However, this grouping is not a strict grouping of taxa, since a given taxon may take advantage of snow in several ways. For instance, the collembolan $H$. socialis uses the advantages $1,2,3$ and 5 , 
TABLE 1. Ecological, behavioural and physiological characteristics of four wingless arthropods that are regularly active on the snow surface. Compilation from several sources mentioned in the text. B. w. = Boreus westwoodi, B. h. = Boreus hyemalis.

\begin{tabular}{|c|c|c|c|c|c|c|c|c|c|c|c|c|c|}
\hline & \multicolumn{4}{|c|}{ Purpose of winter activity } & \multicolumn{2}{|c|}{ Behaviour } & \multirow[b]{2}{*}{$\begin{array}{l}\text { Phenology } \\
\text { (Main } \\
\text { activity) }\end{array}$} & \multicolumn{2}{|c|}{ Weather } & \multicolumn{4}{|c|}{ Reactions to temperature } \\
\hline & $\begin{array}{l}\text { Migra- } \\
\text { tion }\end{array}$ & $\begin{array}{l}\text { Egg- } \\
\text { laying }\end{array}$ & Feeding & $\begin{array}{l}\text { Copu- } \\
\text { lation }\end{array}$ & $\begin{array}{l}\text { Jum- } \\
\text { ping }\end{array}$ & $\begin{array}{l}\text { Naviga- } \\
\text { tion by } \\
\text { sun }\end{array}$ & & $\begin{array}{l}\text { Typical } \\
\text { temp. }\end{array}$ & $\begin{array}{l}\text { Cloudy } \\
\text { or } \\
\text { sunny }\end{array}$ & $\begin{array}{l}\text { Prefer- } \\
\text { ence } \\
\text { temp. }\end{array}$ & $\begin{array}{c}\text { Temp. of } \\
\text { body fluid } \\
\text { freezing }\end{array}$ & $\begin{array}{l}\text { Chill } \\
\text { coma } \\
\text { temp. }\end{array}$ & $\begin{array}{l}\text { Super- } \\
\text { cooling } \\
\text { point }\end{array}$ \\
\hline $\begin{array}{l}\text { Chionea araneoides } \\
\text { (Diptera: } \\
\text { Limoniidae) } \\
\end{array}$ & Yes & $\begin{array}{l}\text { Yes } \\
\text { (No } \\
\text { refill) } \\
\end{array}$ & No & Rarely & No & No & $\begin{array}{l}\text { January- } \\
\text { February }\end{array}$ & $\begin{array}{l}\text { From } \\
-5 \text { to } \\
+1^{\circ} \mathrm{C} \\
\end{array}$ & Cloudy & $\begin{array}{c}\text { Chionea } \\
\text { sp.: } \\
-3^{\circ} \mathrm{C} \\
\end{array}$ & $-0.7^{\circ} \mathrm{C}$ & $-5.5^{\circ} \mathrm{C}$ & $-7.5^{\circ} \mathrm{C}$ \\
\hline $\begin{array}{l}\text { Boreus sp. } \\
\text { (Mecoptera) }\end{array}$ & Yes & $\begin{array}{c}\text { Yes } \\
\text { (Refill) }\end{array}$ & $\begin{array}{c}\text { Yes } \\
\text { (Moss) }\end{array}$ & Rarely & Yes & Yes? & $\begin{array}{c}\text { November- } \\
\text { December } \\
\text { and March-- } \\
\text { April } \\
\end{array}$ & $\begin{array}{l}\text { From } \\
-1 \text { to } \\
+5^{\circ} \mathrm{C}\end{array}$ & $\begin{array}{l}\text { Cloudy } \\
\text { or } \\
\text { sunny }\end{array}$ & $\begin{array}{l}\text { B. w.: } \\
+4^{\circ} \mathrm{C} \\
\text { B. h.: } \\
+10^{\circ} \mathrm{C} \\
\end{array}$ & $\begin{array}{l}\text { B. w.: } \\
-0.7^{\circ} \mathrm{C} \\
\text { B. h.: } \\
-0.6^{\circ} \mathrm{C}\end{array}$ & $\begin{array}{l}\text { B. w.: } \\
-5.5^{\circ} \mathrm{C} \\
\text { B. h.: } \\
-4.1^{\circ} \mathrm{C}\end{array}$ & $\begin{array}{l}\text { B. w.: } \\
-5.6^{\circ} \mathrm{C} \\
\text { B. h.: } \\
-5.7^{\circ} \mathrm{C} \\
\end{array}$ \\
\hline $\begin{array}{l}\text { Hypogastrura } \\
\text { socialis } \\
\text { (Collembola) }\end{array}$ & Yes & No & No & No & Yes & Yes & $\begin{array}{c}\text { March-- } \\
\text { April }\end{array}$ & $\begin{array}{l}\text { From } \\
0 \text { to } \\
+5^{\circ} \mathrm{C} \\
\end{array}$ & Sunny & $?$ & $?$ & $?$ & $?$ \\
\hline $\begin{array}{l}\text { Bolephthyphantes } \\
\text { index } \\
\text { (Araneae: } \\
\text { Linyphiidae) }\end{array}$ & Yes & $?$ & $\begin{array}{c}\text { Yes } \\
\text { (Catching } \\
\text { Collembola } \\
\text { etc. in web } \\
\text { on snow) }\end{array}$ & Yes & No & No & $\begin{array}{c}\text { March- } \\
\text { April }\end{array}$ & $\begin{array}{l}\text { From } \\
0 \text { to } \\
+5^{\circ} \mathrm{C}\end{array}$ & $\begin{array}{l}\text { Cloudy } \\
\text { or } \\
\text { sunny }\end{array}$ & $+4^{\circ} \mathrm{C}$ & $-1.2^{\circ} \mathrm{C}$ & $-9.3^{\circ} \mathrm{C}$ & $-15.3^{\circ} \mathrm{C}$ \\
\hline
\end{tabular}

and Chionea and Boreus the advantages 2, 3, and may be 6. Nevertheless, listing the various advantages is useful for a general understanding of arthropod life in and on snow.

\section{Grouping according to specialization for winter activity}

Which are the most specialized snow arthropods? At least three wingless taxa turn out to have an obligatory snow surface activity, representing a natural part of their life cycle in Fennoscandia: Chionea and Boreus have an obligatory egg-laying period during winter, and the collembolan $H$. socialis has an obligatory dispersion phase. Chionea shows strong cold tolerance by being active in a supercooled state close to its chill-coma temperature, and by laying its eggs during mid-winter. Boreus and $H$. socialis have both developed an advanced migration behaviour based on a combination of jumping and navigation. The possibility of efficient dispersion on a smooth and practically predation-free snow surface is important for these three wingless taxa. The absence of wings in Chionea and Boreus is probably itself an adaptation to low temperatures when flight is difficult. Tahvonen (1942) likewise included these three taxa among the "real winter insects", which are found as adults only during winter.

Other regularly occurring arthropods on snow are more difficult to categorize. How crucial is the prolonged survival and egg-laying of certain Trichoceridae? How large a portion of the population of the spider $B$. index starts feeding and reproduction early by constructing webs on the snow surface? Would Plecoptera and Chironomidae hatching from winter-open brooks manage as well without the presence of snow? Is the supranivean activity of a number of flies and spiders just a continuation of subnivean acivity of cold tolerant species? Generally, the regular subnivean activity of a number of invertebrate groups is poorly understood.

Grouping according to activity below, in and on snow

Strictly, the terms subnivean, intranivean and supranivean are habitat terms, but are often used as terms for dif- ferent arthropod communities or species assemblages. In practice, several taxa migrate between these habitats. The intranivean fauna and most of the supranivean fauna is recruited from the subnivean "base camp". However, the subnivean habitat also contains several winter-active taxa (for instance, beetles and spiders) that never visit the intranivean or supranivean habitat. While the supranivean fauna is absent in very cold weather, the intranivean microarthropods represent a rather stable "community" throughout winter, although they may be forced down to the lower snow layers during very cold periods.

Grouping of supranivean arthropods according to phenology and weather

The supranivean arthropod fauna can be predicted by two parameters. The first is the winter month, taking into account the phenology of each species. The second are the actual weather conditions. Below about $-6^{\circ} \mathrm{C}$, the snow surface fauna is absent, and the richest fauna is found at temperatures around $0^{\circ} \mathrm{C}$. Furthermore, the cloud conditions are important, as some species prefer sunny weather and others prefer cloudy conditions. Wind generally has a negative effect on snow surface arthropods, maybe due to dehydration and/or cooling. With a good knowledge of the phenology and weather preferences for each species, it is often possible to predict the supranivean arthropod fauna rather well on a given day. Nevertheless, there may be a "delayed response" of one or more days to changed weather conditions. For instance, a sudden mild period may not immediately be noted by animals waiting in cooler snow layers or in the subnivean environment.

Fig. 21 shows a simplified picture of the most typical month, temperature and cloud conditions when Chionea, Boreus, $H$. socialis and B. index are present on snow. The figure is based mainly on data from south Norway. In reality, niches overlap more than indicated in the figure, and Boreus and $H$. socialis may for instance appear on snow during mid winter if mild periods occur.

Based on a large data set from Finland, Tahvonen (1942) grouped the insect fauna on snow in four catego- 


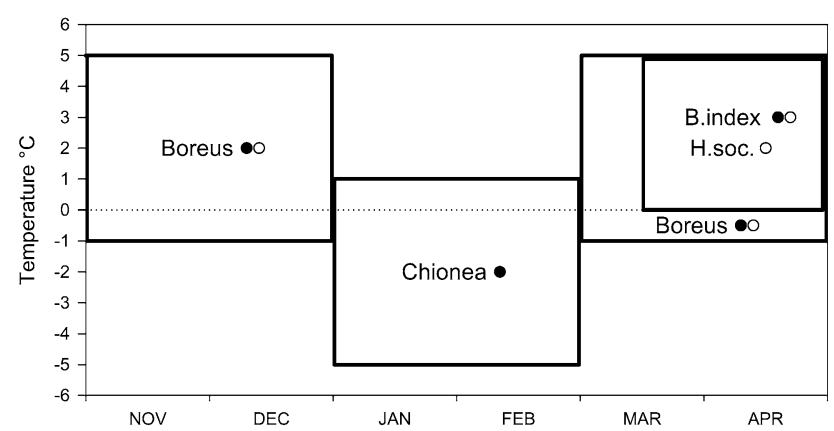

Fig. 21. Typical combinations of month and temperature, when the most specialized and wingless "snow arthropods" are active on the snow surface: Boreus sp. (Mecoptera), Chionea araneoides (Diptera: Limoniidae), Hypogastrura socialis (Collembola: Hypogastruridae), and Bolephthyphantes index (Araneae: Linyphiidae). Open circles: sunny weather, dark circles: overcast weather. In practice, the squares overlap more than shown here, and all groups may be found together.

ries, mainly based on phenology: 1. Real winter insects, which are found as adults only during winter (Chionea sp., Boreus sp., H. socialis, and three Isotoma species). 2. Summer species which are regularly observed on snow: Six springtail species, among which Entomobrya nivalis (L.) was active on snow down to $-9.5^{\circ} \mathrm{C}$. 3. Autumn and spring species which regularly appear on snow: Three species of Trichocera (Diptera: Trichoceridae): T. regelationis, T. hiemalis, and T. maculipennis Meigen). 4. Summer species which accidentally occur on snow. This group of 93 recorded species from various taxa was dominated by Coleoptera (60 species). From long-term studies in northern Finland, Viramo (1983a) stressed the influence of weather conditions on the snow surface fauna. Regarding phenology, he divided the winter roughly into three periods. During early winter, from October to November, many species of spiders and beetles dominated on snow. Midwinter, from December to March, was poor in animals, and Diptera dominated the snow surface. In late winter, starting from April, Mecoptera were most abundant, and many accidental species were found.

\section{Evolutionary aspects}

The various adaptations to winter activity indicate a long evolution. Independently, species from quite different taxonomic groups have evolved mechanisms to take advantage of the snow-covered period during a certain phase of their life cycle. Predation-free migration of wingless species on a smooth surface is a common factor for several species. Beside morphological and physiological adaptations, especially noteworthy is the ability among Collembola species to navigate, which implies a complex behaviour.

As stressed by Leinaas (1983c), the evolution of winter activity can only be understood by also studying the animals during the summer (i.e. when they feed, reproduce, are preyed upon or possibly compete). The collembolan $H$. socialis illustrates how winter activity fits into the entire life cycle in a meaningful way. During winter, colonies are efficiently rearranged through intense migration activity in a non-feeding and non-reproductive phase.

Many groups and species of Fennoscandian arthropods are sufficiently cold tolerant to be active within or on snow. However, only a few of them belong to the "real snow arthropods" which actively take advantage of snow to fulfil their life cycle. Species active on the snow surface seem to represent more or less a continuum, from highly specialized winter active species to random visitors. Some may represent evolutionary steps towards real snow arthropods. For instance, Chironomidae copulating on snow without flying may gradually end up as a wingless species. From alpine habitats at Finse, south Norway, Willassen (1985) described Diamesa saetheri, a coldadapted species with nearly wingless females, being active on snow patches during summer. Larvae develop in water which is often close to $0^{\circ} \mathrm{C}$ (Willassen, pers. comm.).

Among spiders, there is an available niche for more species to harvest from the snow surface fauna, especially when mass migrations of Collembola occur. In general, the smooth snow surface represents a potential for more wingless arthropods to evolve dispersal behaviour during the winter.

More detailed Fennoscandian studies on arthropod activity in the subnivean habitat are needed. The subnivean environment is the "base camp" for most species occurring on snow. It is also an evolutionary base camp for new species to adapt to intranivean or supranivean activity.

ACKNOWLEDGEMENTS. H.P. Leinaas is heartily thanked for critical reading of the manuscript. S. Koponen and E. Krzeminska kindly identified the photographed Tenuiphantes cristatus and Trichocera regelationis, respectively. H. Elven and N. Sloth offered photos of Chionea araneoides, H.-J. Skar of mass occurrence of Hypogastrura socialis, and G. Hågvar of Bolephthyphantes index in web on snow. J. Meadow corrected the language. Four anonymous referees gave valuable advice.

\section{REFERENCES}

AAKRA K. 1998: Epigeic Spiders of the Island of Askøy, Western Norway. Cand. Scient. thesis, Zoological Museum, University of Bergen, $148 \mathrm{pp}$.

Aitchison C.W. 2001: The effect of snow cover on small animals. In Jones H.G., Pomeroy J.W., Walker D.A. \& Hoham R.W. (eds): Snow Ecology: An Interdisciplinary Examination of Snow-Covered Ecosystems. Cambridge University Press, Cambridge, pp. 229-265.

BÄHRMANN R. 1996: Winteraktive Zweiflügler (Insecta, Diptera Brachycera) in Xerothermrasen Thüringens. Studia Dipt. (Saale) 3: 259-274.

Block W. \& Zettel J. 1980: Cold hardiness of some alpine Collembola. Ecol. Entomol. 5: 1-9.

Bouchard R.W. \& Ferrington L.C. 2009: Winter growth, development, and emergence of Diamesa mendotae (Diptera: Chironomidae) in Minnesota streams. Environ. Entomol. 38: 250-259.

BrincK P. 1949: Studies on Swedish stoneflies. Opusc. Entomol. (Suppl.) 11: 1-250. 
Brummer-Korvenkontio M. \& Brummer-Korvenkontio L. 1980: Springtails (Collembola) on and in snow. Mem. Soc. Fauna Flora Fenn. 56: 91-94.

CoOper K.W. 1974: Sexual biology, chromosomes, development, life histories and parasites of Boreus, especially B. notoperates. A southern California Boreus II (Mecoptera, Boreidae). Psyche 81: 84-120.

Coulianos C.-C. \& Johnels A.G. 1962: Note on the subnivean environment of small mammals. Ark. Zool. (Ser. 2): 363-370.

Courtin G.M., Shorthouse J.D. \& West R.J. 1984: Energy relations of the snow scorpionfly Boreus brumalis (Mecoptera) on the surface of the snow. Oikos 43: 241-245.

Czerny L. 1927: Fam. 53a. Heleomyzidae. In Lindner E. (ed.) Die Fliegen der Palaearktischen Region. Vol. 5. E. Schweizerbart'sche Verlagsbuchhandlung, Stuttgart, pp. 1-46.

DAHL C. 1965: Studies on swarming activity in Trichoceridae (Diptera) in Southern Sweden. Opusc. Entomol. (Suppl.) 27: $1-68$.

DAHL C. 1969: The influence of light, humidity and temperature on Trichoceridae (Diptera). Oikos 20: 409-430.

DAHL C. 1970: Distribution, phenology and adaptation to arctic environment in Trichoceridae (Diptera). Oikos 21: 185-202.

DAHL C. 1974: Winter gnats (Diptera, Nemat.: Trichoceridae) in the Messaure area. Norrbottens Läns Naturvårdsförbund 30: 52-54 [in Swedish, with English abstr.].

FAUNA EUROPAEA 2009: http://www.faunaeur.org/species_list. php

FJellberg A. 2007: The Collembola of Fennoscandia and Denmark. Part II: Entomobryomorpha and Symphypleona. Fauna Entomol. Scand. 42: 1-266.

FJellberg A. \& Greve L. 1968: Notes on the genus Boreus in Norway. Norsk Entomol. Tidsskr. 15: 33-34.

FrASER F.C. 1943: Ecological and biological notes on Boreus hyemalis (L.) (Mecopt., Boreidae). J. Soc. Br. Entomol. 2: 125-129.

GeIGer R. 1965: The Climate Near the Ground. Harvard University Press, Cambridge, MA, xiv $+611 \mathrm{pp}$.

HaCKMAN W. 1963: Studies on the Dipterous fauna in burrows of voles (Microtus, Clethrionomys) in Finland. Acta Zool. Fenn. (Helsinki) 102: 1-64.

HÅgVar S. 1971: Field observations on the ecology of a snow insect, Chionea araneoides Dalm. (Dipt., Tipulidae). Norsk Entomol. Tidsskr. 18: 33-37.

HÅGVAR S. 1973: Ecological studies on a winter-active spider Bolyphantes index (Thorell) (Araneida, Linyphiidae). Norsk Entomol. Tidsskr. 20: 309-314.

HÅgvar S. 1976a: Phenology of egg development and egglaying in a winter-active insect, Chionea araneoides Dalm. (Dipt., Tipulidae). Norw. J. Entomol. 23: 193-195.

HÅgVaR S. 1976b: Winter-active insects enclosed by ice from supercooled rain. Norw. J. Entomol. 23: 204.

HÅgVar S. 1995: Long distance, directional migration on snow in a forest collembolan, Hypogastrura socialis (Uzel). Acta Zool. Fenn. (Helsinki) 196: 200-205.

HÅgVaR S. 2000: Navigation and behaviour of four Collembola species migrating on the snow surface. Pedobiologia 44: 221-233.

HÅgVAR S. 2001: Occurrence and migration on snow, and phenology of egg-laying in the winter-active insect Boreus sp. (Mecoptera). Norw. J. Entomol. 48: 51-60.

HAgvar S. 2007: Why do some Psylloidea and Heteroptera occur regularly on snow? Norw. J. Entomol. 54: 3-9.

HÅgVar S. \& AaKRa K. 2006: Spiders active on snow in Southern Norway. Norw. J. Entomol. 53: 71-82.
HÅgVar S. \& FJellberg A. 2002: Autumn migration of a colony of Hypogastrura socialis (Uzel) (Collembola, Hypogastruridae). Norw. J. Entomol. 49: 145-146.

HÅgvar S. \& Greve L. 2003: Winter active flies (Diptera, Brachycera) recorded on snow - a long-term study in south Norway. Studia Dipt. (Saale) 10: 401-421.

HÅgVAR E.B. \& HÅGVAR S. 1975: Studies on the invertebrate fauna on branches of spruce (Picea abies (L.)) during winter. Norw. J. Entomol. 22: 23-30.

HÅgVAR S. \& ØStBYe E. 1973: Notes on some winter-active Chironomidae. Norsk Entomol. Tidsskr. 20: 253-257.

HÅgVAR S. \& KRzeminsKa E. 2007: Contribution to the winter phenology of Trichoceridae (Diptera) in snow-covered southern Norway. Studia Dipt. (Saale) 14: 271-283.

HeRTER K. 1953: Der Temperatursinn der Insekten. Duncker \& Humblot, Berlin, 378 pp.

Huhta V. \& Viramo J. 1979: Spiders active on snow in northern Finland. Ann. Zool. Fenn. 16: 169-176.

Husby J.A. \& Zachariassen K.E. 1980: Antifreeze agents in the body fluid of winter active insects and spiders. Experientia 36: 963-964.

JonsSON B. \& SANDLUND O.T. 1975: Notes on winter activity of two Diamesa species (Dipt., Chironomidae) from Voss, Norway. Norw. J. Entomol. 22: 1-6.

Koponen S. 1976: Spider fauna (Araneae) of Kevo area, northernmost Finland. Rep. Kevo Subarctic Res. Stat. 13: 48-62.

Koponen S. 1983: The arthropod fauna on the snow surface in Northern Lapland. Oulanka Reports 4: 58-61.

Koponen S. 1989: Spiders (Araneae) on snow surface in subarctic Lapland. Aquilo (Ser. Zool.) 24: 91-94.

KRZEMINSKA E. 2009: Trichoceridae (winter crane flies). In Brown B.V., Borkent A., Cumming J.M., Wood D.M., Woodley N.E. \& Zumbado M. (eds): Manual of Central American Diptera. Vol. 1. NRC Research Press, Ottawa, pp. 337-340.

LAURENCE B.R. 1956: On the life history of Trichocera saltator (Harris) (Diptera, Trichoceridae). Proc. Zool. Soc. Lond. 126: 235-243.

LeINAAS H.P. 1980: Isotoma blekeni n. sp. (Collembola: Isotomidae) from coniferous forest in Norway. Ecological segregation of related, coexisting species. Rev. Ecol. Biol. Sol 17: 281-289.

LEINAAS H.P. 1981a: Activity of Arthropoda in snow within a coniferous forest, with special reference to Collembola. Holarct. Ecol. 4: 127-138.

LEINAAS H.P. 1981b: Cyclomorphosis in the furca of the winter active Collembola Hypogastrura socialis (Uzel). Entomol. Scand. 12: 35-38.

LeINAAS H.P. 1981c: Cyclomorphosis in Hypogastrura lapponica (Axelson, 1902) (= H. frigida (Axelson, 1905) syn. nov.) (Collembola, Poduridae). Morphological adaptations and selection for winter dispersal. Z. Zool. Syst. Evol.-Forsch. 19: 278-285.

LeInaAs H.P. 1983a: Surface Dwelling Collembola in Variable Environments. Demographic, Behavioural and Physiological Adaptations. PhD. thesis, Univ. of Oslo.

LeINAAS H.P. 1983b: Synchronized moulting controlled by communication in group-living Collembola. Science 219: 193-195.

LeinaAs H.P. 1983c: Winter strategy of surface dwelling Collembola. Pedobiologia 25: 235-240.

LeinaAs H.P. 1988: Anal sacks - an unknown organ in Poduromorpha (Collembola). Zool. Scr. 17: 277-284. 
LeinaAs H.P. \& Fuellberg A. 1985: Habitat structure and life history strategies of two partly sympatric and closely related, lichen feeding collembolan species. Oikos 44: 448-458.

Lillehammer A. 1971: The Stoneflies. In Frislid R. \& SembJohansson A. (eds): Norges dyr IV: Virvelløse dyr. J.W. Cappelen, Oslo, pp. 226-230 [in Norwegian].

LillehAmmer A. 1988: Stoneflies (Plecoptera) of Fennoscandia and Denmark. Fauna Entomol. Scand. 21: 1-165.

Munari L., Vanin S. \& Turchetto M. 1997: Lesser dung fly species collected in the nival horizon of the Dolomites (NE Italy) (Diptera: Sphaeroceridae). Boll. Soc. Entomol. Ital. 129: $251-255$.

NäSMARK O. 1964: Winter activity under the snow in land-living invertebrates. Zoologisk Revy 1: 5-15 [in Swedish, English abstr.].

Nuorteva M. 1951: Observations on some winter-insects. Ann. Entomol. Fenn. 17: 117 [in Finnish, English abstr.).

Oliver D.R. 1968: Adaptations of Arctic Chironomidae. Ann. Zool. Fenn. 5: 111-118.

Oosterbroek P. \& Reusch H. 2008: Review of the European species of the genus Chionea Dalman, 1816 (Diptera, Limoniidae). Braunschweig. Naturkd. Schr. 8(1): 173-220.

ØstвYe E. 1963: A Study on the Ecology of Nival Carabids, Especially within the Genus Nebria Latr. Cand. Real. Thesis, University of Oslo, 99 pp. [in Norwegian].

ØstвYE E. 1966: The spider which catches springtails in web during winter. Fauna (Oslo) 19: 43 [in Norwegian, English abstr.].

Papp L. 1981: 54. Heleomyzidae. Fauna Hung. (Budapest) 149: $1-137$.

PruitT W.O. JR. 1970: Some ecological aspects of snow. In UNESCO (ed.): Ecology of the Subarctic Regions. Paris, pp. $83-100$.

SAuer C.-P. 1966: Ein Eskimo unter den Insekten: Der Winterhaft Boreus westwoodi. Mikrokosmos 55: 117-120.

Skulberg O.M. \& Skulberg V.M. 2003: Knowledge about mass occurrence/migration of Hypogastrura socialis (Collembola, Hypogastruridae) in Spydeberg, Østfold, Norway. Fauna (Oslo) 56: 20-31 [in Norwegian, English abstr.].

SøмmE L. 1999: The physiology of cold hardiness in terrestrial arthropods. Eur. J. Entomol. 96: 1-10.

Søмme L. \& Øsтвye E. 1969: Cold-hardiness in some winter active insects. Norsk Entomol. Tidsskr. 16: 45-48.

STEINER P. 1937: Beitrag zur Fortpflanzungsbiologie und Morphologie des Genitalapparates von Boreus hiemalis L. Z. Morphol. Ökol. Tiere 32: 276-288.

SosZYNSKA A. 2004: The influence of environmental factors on the supranivean activity of flies (Diptera) in Central Poland. Eur. J. Entomol. 101: 481-489.

STRÜBING H. 1950: Beiträge zur Biologie von Boreus hiemalis L. Zool. Beitr. N.F. I: 51-110.
Svensson S.A. 1966: Studies on the biology of certain winter active insects. Norsk Entomol. Tidsskr. 13: 335-338 [in Swedish].

Svensson S.A. 1972: Boreus Latreille, 1825 (Mecoptera). A synopsis of described species. Entomol. Scand. 3: 26-32.

TAhVonen E. 1942: Beobachtungen über Winterinsekten. Ann. Entomol. Fenn. 8: 203-214.

UlfSTRAND S. 1968: Life cycles of benthic insects in Lapland streams (Ephemeroptera, Plecoptera, Trichoptera, Diptera Simuliidae). Oikos 19: 167-190.

VANIN S. 2008: Chionea (Chionea) mirabilis n. sp., a new species of snow fly (Insecta, Diptera, Limoniidae) from Korea. Zoosystema 30: 413-418.

VAnin S. \& Masutti L. 2008: Studies on the distribution and ecology of snow flies Chionea lutescens and Chionea alpina (Diptera, Limoniidae) in Italy. Ital. J. Zool. 75: 147-153.

VANIN S. \& TURChetTo M. 2007: Winter activity of spiders and pseudoscorpions in the South-Eastern Alps (Italy). Ital. J. Zool. 74: 31-38.

Vanin S., Bubacco L. \& Beltramini M. 2008: Seasonal variation of trehalose and glycerol concentrations in winter snowactive insects. CryoLetters 29: 485-491.

VIRAMO J. 1983a: Invertebrates active on snow in northern Finland. Oulanka Reports 3: 47-52.

VIRAMO J. 1983b: Invertebrates under the snow and in snow samples. Oulanka Reports 4: 62-65.

Willassen E. 1985: A review of Diamesa davisi Edwards and the davisi group. Spixiana (Suppl.) 11: 109-137.

Withyсомве C.L. 1922: On the life-history of Boreus hyemalis L. Trans. Entomol. Soc. Lond. 1921: 312-319.

WOJTUSIAK H. 1950: The temperature preferendum of winter insects of the genus Boreus (Panorpatae) and Chionea (Diptera). Bull. Ac. Pol. Sci. Lettr. (B) 11: 125-143.

ZERNECKE R. 1999: Streifenförmige Wanderzüge von Hypogastrura socialis (Uzel) (Collembola, Hypogastruridae). Mitt. Münch. Entomol. Ges. 89: 95-117.

ZetTel J. 1984a: The significance of temperature and barometric pressure changes for the snow surface activity of Isotoma hiemalis (Collembola). Experientia 40: 1369-1372.

ZetTel J.1984b: Cold hardiness strategies and thermal hysteresis in Collembola. Rev. Ecol. Biol. Sol 21: 189-203.

Zettel J. 1985: Die Cyclomorphose von Isotoma hiemalis (Collembola): Endogene Steuerung, phänologische und physiologische Aspekte. Zool. Jb. Syst. 112: 383-404.

Zettel J., Zettel U., Suter C., Streich S. \& Egger B. 2002: Winter feeding behaviour of Ceratophysella sigillata (Collembola: Hypogastruridae) and the significance of eversible vesicles for resource utilization. Pedobiologia 46: 404-413.

Received December 1, 2009; revised and accepted April 12, 2010 